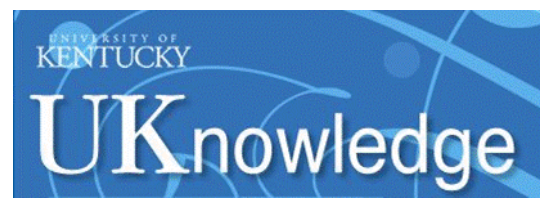

University of Kentucky

UKnowledge

Microbiology, Immunology, and Molecular Genetics Faculty Publications

Microbiology, Immunology, and Molecular

Genetics

8-15-2008

\title{
CD5 Plays an Inhibitory Role in the Suppressive Function of Murine $\mathrm{CD} 4^{+} \mathrm{CD} 25^{+} \mathrm{T}_{\text {reg }}$ Cells
}

\author{
Trivikram Dasu \\ University of Kentucky \\ Joseph E. Qualls \\ University of Kentucky \\ Halide Tuna \\ University of Kentucky, htuna2@uky.edu \\ Chander Raman \\ University of Alabama at Birmingham \\ Donald A. Cohen \\ University of Kentucky, don.cohen@uky.edu \\ Follow this and additional works at: https://uknowledge.uky.edu/microbio_facpub

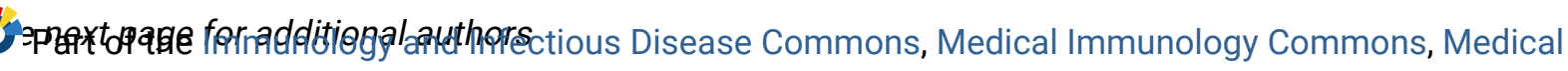 \\ Microbiology Commons, and the Molecular Genetics Commons \\ Right click to open a feedback form in a new tab to let us know how this document benefits you.
}

\section{Repository Citation}

Dasu, Trivikram; Qualls, Joseph E.; Tuna, Halide; Raman, Chander; Cohen, Donald A.; and Bondada,

Subbarao, "CD5 Plays an Inhibitory Role in the Suppressive Function of Murine CD4 ${ }^{+}$CD25 ${ }^{+}$Treg Cells" (2008). Microbiology, Immunology, and Molecular Genetics Faculty Publications. 123.

https://uknowledge.uky.edu/microbio_facpub/123

This Article is brought to you for free and open access by the Microbiology, Immunology, and Molecular Genetics at UKnowledge. It has been accepted for inclusion in Microbiology, Immunology, and Molecular Genetics Faculty Publications by an authorized administrator of UKnowledge. For more information, please contact UKnowledge@lsv.uky.edu. 


\section{CD5 Plays an Inhibitory Role in the Suppressive Function of Murine CD4 ${ }^{+}$CD25 $5^{+}$ Treg Cells}

\section{Digital Object Identifier (DOI)}

https://doi.org/10.1016/j.imlet.2008.05.008

\section{Notes/Citation Information}

Published in Immunology Letters, v. 119, issues 1-2, p. 103-113.

Copyright @ 2008 Elsevier B.V. All rights reserved.

This manuscript version is made available under the CC-BY-NC-ND 4.0 license

http://creativecommons.org/licenses/by-nc-nd/4.0/.

The document available for download is the author's post-peer-review final draft of the article.

\section{Authors}

Trivikram Dasu, Joseph E. Qualls, Halide Tuna, Chander Raman, Donald A. Cohen, and Subbarao Bondada 


\title{
CD5 plays an inhibitory role in the suppressive function of murine CD4+ CD25+ $T_{\text {reg }}$ cells
}

\author{
Trivikram Dasu ${ }^{1}$, Joseph E Qualls ${ }^{1}$, Halide Tuna ${ }^{1}$, Chander Raman ${ }^{2}$, Donald A Cohen ${ }^{1}$, and \\ Subbarao Bondada $1,3,4$
}

1 Department of Microbiology, Immunology \& Molecular Genetics

2Department of Medicine, University of Alabama at Birmingham, $A L$

3Sanders Brown Center on Aging, University of Kentucky, Lexington, KY 40536-0230

4Markey Cancer Research Center

\section{Abstract}

A subset of $\mathrm{CD} 4^{+} \mathrm{T}$ cells, the $\mathrm{CD} 4^{+} \mathrm{CD} 25^{+} \mathrm{T}_{\text {reg }}$ cells in the lymphoid organs and peripheral blood are known to possess suppressive function. Previous in vitro and in vivo studies have indicated that T cell receptor (TCR) signal is required for development of such 'natural regulatory $\left(\mathrm{T}_{\text {reg }}\right)$ cells' and for activation of the effector function of $\mathrm{CD} 4^{+} \mathrm{CD} 25^{+}$regulatory $\mathrm{T}$ cells. $\mathrm{CD} 5$ is a cell surface molecule present on all $\mathrm{T}$ cells and a subtype of B lymphocytes, the B-1 cells, primarily localized to coelomic cavities, Peyer's patches, tonsils and spleen. CD5 acts as a negative regulator of T cell and $B$ cell signaling via recruitment of SHP- 1 . Here, we demonstrate that $T_{\text {reg }}$ cells obtained from $\mathrm{CD}^{-1-}$ mice are more potent than those from wild type mice in suppressing the in vitro cell proliferation of anti-CD3 stimulated $\mathrm{CD} 4^{+} \mathrm{CD} 25^{-}$responder $\mathrm{T}$ cells. This phenomenon was cell contact and GITR dependent. Lack of CD5 expression on $\mathrm{T}_{\text {reg }}$ cells (from spleen, lymph node and thymus) did not affect the intracellular levels of Foxp3. However, $\mathrm{CD}^{-1-} \mathrm{T}_{\text {reg }}$ thymocytes were able to elicit a higher $\mathrm{Ca}^{2+}$ response to TCR + co-stimulatory signals than the wild type cells. $\mathrm{CD}^{-1-}$ mice expressed more Foxp3 mRNA in the colon than wild type mice, and additionally, the severity of the DSS-induced colitis in $\mathrm{CD} 5^{-1-}$ mice was less than the wild type strain. We suggest that manipulation of CD5 expression or the downstream signaling components of $\mathrm{CD} 4{ }^{+} \mathrm{CD} 25^{+} \mathrm{T}_{\text {reg }}$ cells as a potential strategy for therapeutic intervention in cases of auto-immune disorders.

\author{
Keywords \\ murine $\mathrm{CD} 4^{+} \mathrm{CD} 25^{+} \mathrm{T}_{\text {reg }}$ cells; CD5; DSS-colitis
}

\section{Introduction}

The recently described $\mathrm{CD} 4{ }^{+} \mathrm{CD} 25^{+}$regulatory $\mathrm{T}\left(\mathrm{T}_{\text {reg }}\right)$ cells are critical for peripheral tolerance. They potently suppress the function of effector $\mathrm{T}$ cells. The dominant form of peripheral tolerance induction by the $\mathrm{CD} 4^{+} \mathrm{CD} 25^{+} \mathrm{T}_{\text {reg }}$ cells has been implicated to have great

\footnotetext{
Address correspondence to: Subbarao Bondada, PhD, 303 Combs Cancer Bldg, 800 Rose Street, University of Kentucky, Lexington, KY 40536-0096. E-mail: bondada @email.uky.edu, Tel: (859) 323-4705, Fax: (859) 257-8940.

Publisher's Disclaimer: This is a PDF file of an unedited manuscript that has been accepted for publication. As a service to our customers we are providing this early version of the manuscript. The manuscript will undergo copyediting, typesetting, and review of the resulting proof before it is published in its final citable form. Please note that during the production process errors may be discovered which could affect the content, and all legal disclaimers that apply to the journal pertain.
} 
clinical relevance in both systemic and organ specific autoimmune diseases as well as infectious diseases $(1,2)$. The precise mechanism ( $\mathrm{s}$ ) of the $\mathrm{T}_{\text {reg }}$ mediated suppression of naïve or effector $\mathrm{T}$ cells in the secondary lymphoid organs and other sites of active inflammation has not been deciphered completely (3). It is thought that the $T_{\text {reg }}$ cells block IL-2 production and cause $\mathrm{G}_{1}$ arrest in the effector $T$ cell population in a cell contact dependent manner (4). This phenomenon of inhibition of cell proliferation has been proven to be reversible both in vitro and in vivo (5-7). A recent study found that $\mathrm{T}_{\text {reg }}$ cells induce apoptosis of the responder $\mathrm{T}$ cells and that the apoptosis can be reversed by cytokines that signal through the common gamma chain containing receptors (8). There is no absolute cell surface marker to isolate these regulatory $\mathrm{T}$ cell populations in the animal models. However, CD4, CD25, CTLA-4, Glucocorticoid-induced TNF receptor (GITR/TNFRSF18), 4-1BB, OX-40, CD103, CD38, Neuropilin-1 (Nrp-1) are some of the cell surface proteins thought to be expressed on the $\mathrm{T}_{\text {reg }}$ cells $(9,10)$. Foxp3 is a member of the forkhead box transcription factor family that is exclusively expressed in the $\mathrm{T}_{\text {reg }}$ cells constitutively and confers the regulatory behavior of these cells (11-14). Overexpression studies and mutant mice have confirmed that Foxp3 is required for the generation and maintenance of $\mathrm{T}_{\text {reg }}$ cells but its precise role in T-reg function is still being elucidated $(12,15)$.

The suppressive effect of $\mathrm{T}_{\text {reg }}$ cells can be overcome by supplying IL-2 in excess of physiological levels or by blocking with an anti-GITR antibody. In vivo, neutralizing antibodies to TGF- $\beta$ and/or IL-10 can also abrogate $\mathrm{T}_{\text {reg }}$ mediated suppression (16-18). Such therapies to down modulate $\mathrm{T}_{\text {reg }}$ function were effective in enhancing effector $\mathrm{T}$ cell function in cases of tumor immunity and to curb infections $(19,20)$. Attempts to induce $\mathrm{T}_{\text {reg }}$ cell proliferation with heat-shock proteins (HSP) in models of experimental autoimmunity indicate potential therapeutic approaches since such HSP-activated $\mathrm{T}$ cells displayed a $\mathrm{T}_{\text {reg }}$ cell-like phenotype (21). This strategy will prove to be useful in autoimmune conditions wherein it is beneficial to the host if $\mathrm{T}_{\text {reg }}$ cells can more actively inhibit the functioning of autoreactive $\mathrm{T}$ cells. Moreover, administration of dexamethasone, an immunosuppressive glucocorticoid, into wild type $\mathrm{BALB} / \mathrm{c}$ mice led to less $\mathrm{CD} 4^{+} \mathrm{CD} 25^{+} \mathrm{T}$ cell death compared to the $\mathrm{CD} 4^{+} \mathrm{CD} 25^{-} \mathrm{T}$ cell apoptosis (22). In this context, we show here that CD5, a cell surface receptor expressed on $\mathrm{T}$ cells is influential in regulating the suppressive nature of $\mathrm{T}_{\text {reg }}$ cells in an in vitro cell co-culture system.

CD5 is a $67 \mathrm{kDa}$ membrane glycoprotein that is expressed on all $\mathrm{T}$ cells and a small subset of $\mathrm{B}$ cells, the B-1 type of B lymphocytes; CD5 acts as a negative regulator of $\mathrm{T}$ cell receptor signaling in thymocytes and of B cell receptor signaling in B-1 cells $(23,24)$. This occurs via recruitment of a protein tyrosine phosphatase, SHP-1, to the cytoplasmic ITIM (immunotyrosine receptor based inhibitor motif) domain of CD5 upon TCR activation (25). Thus, thymocytes obtained from $\mathrm{CD}^{-/-}$mice are hyper-responsive to antigen receptor signaling (24). Introduction of transgenic CD5 into $\mathrm{CD}^{-/-}$mice but not that encoding a truncated form of $\mathrm{CD} 5$ protein was able to rescue the $\mathrm{CD}^{-1-}$ phenotype demonstrating the absolute requirement of the cytoplasmic tail of CD5 for its inhibitory function of TCR signaling in thymocytes (26). CD5 has also been shown to have a role in T cell anergy induced by chronic antigen exposure (27). More recently, in a model of $\mathrm{T}$ cell tolerance induced by antigen targeted to dendritic cells, the $\mathrm{T}$ cell unresponsiveness was linked to increased CD5 expression (28).

Since CD5 is present on all $\mathrm{T}$ cells, we hypothesized that it is present even on the CD4 ${ }^{+}$ $\mathrm{CD} 25^{+}$regulatory $\mathrm{T}$ cells and, therefore, has a role in the functioning of these cells. In an in vitro model of $\mathrm{T}_{\text {reg }}$ cell function, we demonstrate that $\mathrm{T}_{\text {reg }}$ cells are more effective in suppression when they are obtained from $\mathrm{CD}^{-1-}$ mice. It has also been known that $\mathrm{T}_{\text {reg }}$ cells are activated in an antigen specific manner but the effector function of these cells is antigen non-specific $(29,30)$. Taking this fact into consideration, we hypothesized that CD5 may modulate the TCR proximal events in the process of $\mathrm{T}_{\text {reg }}$ cell activation. Thus, we concentrated 
on the receptor proximal signaling events in $\mathrm{T}_{\text {reg }}$ function and how it is affected by the absence of the negative regulator CD5. Furthermore, using an in vivo model of DSS-induced colitis, we show that $\mathrm{CD}^{-/-}$mice are more resistant to induction of colitis.

\section{Materials and Methods}

\section{Mice and cell purification}

3 to 4 month old female C57BL/6 wild type or B6-Ly 5.1 mice and age matched CD5 ${ }^{-1-}$ mice in $(\mathrm{C} 57 \mathrm{BL} / 6 \times 129)$ or B6-Ly 5.1 background were used to obtain splenocytes and lymph nodes (inguinal, axillary, superficial cervical, mandibular and mesenteric). $\mathrm{CD} 4^{+} \mathrm{T}$ cells were negatively selected by using mouse CD4 T cell isolation kit (Miltenyi Biotec Inc., Auburn, CA). Purified CD $4^{+}$cells were stained with anti-CD25 FITC (BD Pharmingen, San Diego, $\mathrm{CA}$ ) and sorted for $\mathrm{CD}_{25} 5^{-}$(responder T cells) and $\mathrm{CD} 25^{+}$( $\mathrm{T}_{\text {reg }}$ cells) fractions using a MoFlo Cytometer (Dako Cytomation, Fort Collins, CO). Alternatively, the splenocytes and lymph node cells were separated into the aforesaid two populations by using the mouse $\mathrm{CD}^{+}$ $\mathrm{CD} 25^{+}$regulatory $\mathrm{T}$ cell isolation kit (Miltenyi Biotec Inc., Auburn, CA) according to the manufacturer's instructions. The purity of resultant cell populations was assessed by flow cytometry to be $>95 \%$.

\section{In vitro proliferation assay}

$5-6 \times 10^{4} \mathrm{CD}^{+} \mathrm{CD} 25^{-}$wild type responder T cells in RPMI were cultured in a 96-well plate with equal number of irradiated splenoctyes (2000 rad), $10 \mu \mathrm{g} / \mathrm{ml}$ soluble anti-CD3 (145-2C11), and varying numbers of $\mathrm{CD} 4{ }^{+} \mathrm{CD} 25^{+} \mathrm{T}_{\text {reg }}$ cells from wild type or $\mathrm{CD}^{-/-}$mice. For Transwell experiments, purified $5 \times 10^{5} \mathrm{CD} 4^{+} \mathrm{CD} 25^{-}$responder $\mathrm{T}$ cells from wild type spleen and lymph node were incubated with equal number of antigen presenting cells (APC) as accessory cells and $10 \mu \mathrm{g} / \mathrm{ml}$ anti-CD3 in the presence of 5 or $10 \times 10^{5} \mathrm{CD}^{+} \mathrm{CD}_{2} 5^{+} \mathrm{T}_{\text {reg }}$ cells from $\mathrm{CD}^{-1-}$ mice in a 24 -well plate. $0.4 \mu \mathrm{m}$ pore size Transwell ${ }^{\mathrm{R}}$ (Corning Inc., Corning, $\mathrm{NY}$ ) insert was used to separate the $\mathrm{T}_{\text {reg }}$ cells from responder $\mathrm{T}$ cells wherever indicated. Cultures were incubated at $37^{\circ} \mathrm{C} / 5 \% \mathrm{CO}_{2}$, pulsed with $\left[{ }^{3} \mathrm{H}\right]$ thymidine on day 3 for 6 hours, harvested and read on a $\beta$-counter. Proliferation results are presented as mean of counts per minute $(\mathrm{cpm}) \pm \mathrm{SE}$ of triplicate cultures.

\section{Flow Cytometry and Antibodies}

Purified CD4 ${ }^{+} \mathrm{CD} 25^{+} \mathrm{T}_{\text {reg }}$ cells were activated with anti-CD3 for 48 hours and stained with supernatants from DTA-1 (monoclonal rat $\operatorname{IgG}_{2 \mathrm{a}}$ antibody secreting anti-GITR hybridoma) (a generous gift of Dr. E. Shevach, NIH) followed by anti-rat Ig FITC secondary antibody and analyzed on a FACS Calibur (BD Biosciences, San Jose, CA) (5). Intracellular staining for Foxp3 expression was performed by following the manufacturer's protocol (eBioscience, San Diego, CA) and analyzed on FACS Calibur. Histograms were overlaid using Cell Quest software (Becton Dickinson, San Jose, CA). Surface staining was performed with antiCD4 PE and anti-CD25 FITC antibodies (BD Pharmingen, San Diego, CA) to distinguish $\mathrm{T}_{\text {reg }}$ and responder $\mathrm{T}$ cell populations.

\section{Calcium release analysis}

Intracellular calcium levels were measured by methods described previously (31). Thymocytes were loaded with $1 \mu \mathrm{M}$ Indo- $1 \mathrm{AM}$ per $10 \times 10^{6}$ cells for $30 \mathrm{~min}$ at $37^{\circ} \mathrm{C}$. Cells were then stained with anti-CD8 $\alpha \sim \mathrm{PE}$ (53-6.7) and anti-CD25 FITC (7D4) on ice for $30 \mathrm{~min}$ along with $5 \mu \mathrm{g} / \mathrm{ml}$ biotinylated anti-CD3 (145-2C11) antibodies, washed and resuspended in insulin and progesterone free IF- $2+10 \%$ FBS. Anti-CD8 was used to identify CD4 $4^{+} \mathrm{T}_{\text {reg }}$ and $\mathrm{T}$ cell responders by negatively gating for all $\mathrm{CD} 8^{+}$populations, so that the $\mathrm{CD} 4$ on $\mathrm{T}_{\text {reg }}$ is not crosslinked if a staining antibody to CD4 were to be used. Before analysis, the cells were resuspended 
in pre-warmed media $\left(37^{\circ} \mathrm{C}\right)$ and baseline calcium levels were measured for $30 \mathrm{sec}$. Avidin (Sigma, St. Louis, MO) was added to the cell suspension and calcium levels were measured for a total of $5 \mathrm{~min}$. The ratio of fluorescence $(405 / 545 \mathrm{~nm})$ of the gated CD8 ${ }^{-} \mathrm{CD} 25^{-}$ (responder T cells) and $\mathrm{CD}^{-} \mathrm{CD}^{+} 5^{+}\left(\mathrm{T}_{\text {reg }}\right.$ cells) cells was determined using the MoFlo cytometer (Dako Cytomation Colorado Inc., Fort Collins, CO) and analyzed using the Summit software program. An increase in the ratio of violet to blue fluorescence indicates an increase in the $\mathrm{Ca}^{2+}$ concentration in the cell. Where indicated, biotinylated anti-CD4/L3T4 (RM4-5) and biotinylated anti-CD28 (37.51) from BD Pharmingen were used as co-stimulants.

\section{Semiquantitative Reverse Transcription PCR}

$\mathrm{CD}^{-1-}$ and $\mathrm{C} 57 \mathrm{BL} / 6$ mice were sacrificed and $1.5 \mathrm{~cm}$ of the descending colon from each mouse was snap-frozen in liquid nitrogen and subsequently stored at $-80^{\circ} \mathrm{C}$. Frozen tissues were homogenized in $1 \mathrm{~mL}$ Trizol reagent (Invitrogen, Carlsbad, CA), followed by phenol/ chloroform RNA extraction. RNA was dissolved in nuclease-free water and stored at $-80^{\circ} \mathrm{C}$ until use. RNA was reverse-transcribed for $1 \mathrm{~h}$ at $42^{\circ} \mathrm{C}$ using oligo-dT primers (Promega, Madison, WI). cDNA samples were then amplified in a DNA thermal cycler (PerkinElmer Inc., Boston, MA) using primers specific for GAPDH (sense: 5'-GCT GGA TCC TTC ATT GAC CTC AAC TAC-3'; antisense: 5'-CGA GAA TTC ATA CCA GGA AAT GAG C-3'), and Foxp3 (sense: 5'-GGC CCT TCT CCA GGA CAG A-3'; antisense: 5'-GCT GAT CAT GGC TGG GTT GT-3'). Samples were amplified at subsaturating conditions (28 cycles for GAPDH and 35 cycles for Foxp3). Cycles for both primers were set at a denaturing temperature of $95^{\circ} \mathrm{C} \mathrm{(1} \mathrm{min} \mathrm{for} \mathrm{GAPDH,} 30 \mathrm{sec}$ for Foxp3), annealing temperature of $58^{\circ} \mathrm{C}(1 \mathrm{~min}$ for GAPDH, $30 \mathrm{sec}$ for Foxp3), and elongation temperature of $72^{\circ} \mathrm{C}$ ( $1 \mathrm{~min} 30 \mathrm{sec}$ for GAPDH, $40 \mathrm{sec}$ for Foxp3).

\section{Induction of Colitis}

Colitis was induced according to the procedure of Murthy et al. (32). 3\% Dextran Sulfate Sodium (DSS - MW 36,000-50,000, MP Biomedicals, LLC, Aurora, OH) was dissolved in water (w/v) and given to $\mathrm{C} 57 \mathrm{BL} / 6$ and $\mathrm{CD}^{-1-}$ mice (4 per group) in place of normal drinking water. DSS water was provided ad libitum for 7 days; all mice were sacrificed on day 7. Measurements of the water volume were taken daily to determine the amount of DSS consumed per mouse. The amount of DSS consumed per mouse was comparable between C57BL/6 and $\mathrm{CD}^{-1-}$ mice. The DSS induction of colitis in wild type and $\mathrm{CD}^{-1-}$ mice was repeated three times with similar results.

\section{Clinical Scoring of Colitis}

The clinical scoring of a Disease Activity Index (DAI) for DSS induced colitis was based on weight loss, stool consistency, and bleeding, as previously described $(32,33)$. The DAI was scored $0-4$ for each parameter per mouse and then averaged for each group. Weight loss scores were determined as $0=$ no weight loss, $1=1-5 \%$ weight loss, $2=6-10 \%$ weight loss, $3=11-$ $15 \%$ weight loss, and $4=>15 \%$ weight loss. Stool scores were determined as $0=$ normal stools, $2=$ loose stools, $4=$ diarrhea. Bleeding scores were determined as $0=$ no bleeding, 1 $=$ Positive Guaiac occult blood test (minimal color change to green), $2=$ Positive Guaiac occult blood test (maximal color change to blue), $3=$ blood visibly present in the stool, no clotting on the anus, and $4=$ gross bleeding from the anus with clotting present.

\section{Tissue Preparation for Histology}

After mice are euthanized, the length of the colon was measured and intestine sections were prepared for histology. Sections were placed in cassettes and stored in 10\% buffered formalin until being embedded in paraffin wax. Cross sections were mounted to slides and stained using Hematoxylin and Eosin by the University of Kentucky histology services. 


\section{Microscopic scoring of Colon Pathology}

Histological scoring was based on the method previously described by Berg et al. and Qualls et al. (33,34). In brief, colon tissue cross-sections were fixed, embedded in paraffin, and stained with Hematoxylin and Eosin as described above. Sections were analyzed with a 20X objective. The colon sections were scored 0-4 based on the level of disease pathology: 0 - No change from normal tissue, 1 - Mild inflammation present in the mucosa, comprised mainly of mononuclear cells, with little epithelial damage, 2 - Multifocal inflammation greater than a grade 1 score including mononuclear cells and a few polymorphonuclear cells (neutrophils), crypt glands have pulled away from the basement membrane, mucin depletion from goblet cells, and the epithelium begins to pull away from the mucosa into the lumen, 3 - Mutlifocal inflammation greater than a grade 2 score including both mononuclear cells and neutrophils progressing into the submucosa, crypt abscesses present with increased mucin depletion, presence of epithelial disruption including some ulcers, and 4-Crypts no longer present, severe mucosal inflammation mainly composed of neutrophils, and the epithelium was no longer present. An average of 4 fields of view per colon was evaluated for each mouse. These scores were averaged per group and recorded as the pathology score \pm S.E. All histological interpreters were blinded.

\section{Statistics}

Student $t$ test was employed to determine the statistical significance of differences between group means.

\section{Results \\ $\mathrm{CD4}^{+} \mathrm{CD25}+\mathrm{T}_{\text {reg }}$ cells from $\mathrm{CD5} 5^{-/-}$mice are more potent in suppressing in vitro proliferation of $\mathrm{CD4}^{+} \mathrm{CD25}^{-}$responder $\mathrm{T}$ cells than $\mathrm{T}_{\text {reg }}$ cells from wild type mice}

It is known that the $\mathrm{T}$ cell and $\mathrm{B}$ cell receptor proximal signaling can be inhibited by CD5, a molecule expressed by all $\mathrm{T}$ cells. This negative signaling of $\mathrm{CD} 5$ occurs via a protein tyrosine phosphatase, SHP-1 that is recruited to the cytoplasmic domain of CD5 upon T cell activation (35). We hypothesized that lack of CD5 expression might remove negative effects of CD5 on TCR signaling and thus enhance $T_{\text {reg }}$ function, which is known to be TCR dependent. In order to test this hypothesis we utilized the $\mathrm{CD} 4^{+} \mathrm{CD} 25^{+} \mathrm{T}_{\text {reg: }}$ : $\mathrm{CD} 4^{+} \mathrm{CD} 25^{-}$responder $\mathrm{T}$ cell in vitro co-culture assay system. $\mathrm{T}_{\text {reg }}$ cells derived from the wild type $\mathrm{C} 57 \mathrm{BL} / 6$ mice suppressed the proliferative response of the $\mathrm{CD} 4^{+} \mathrm{CD} 25^{-}$responder cells in a dose-dependent manner. This phenomenon of suppression is also evident when the $\mathrm{T}_{\text {reg }}$ cells are obtained from $\mathrm{CD}^{-1-}$ mice. However, the suppression by $\mathrm{CD}^{-1-} \mathrm{T}_{\text {reg }}$ cells is much more effective than that observed with the wild type $\mathrm{T}_{\text {reg }}$ cells at each ratio of the $\mathrm{T}_{\text {reg: }}$ : responder T cell tested ( $p<$ $0.05)$ (Fig. 1A). The increased potency of $\mathrm{CD}^{-/-} \mathrm{T}_{\text {reg }}$ cells was observed whether the responder $\mathrm{CD} 4^{+} \mathrm{CD} 25^{-} \mathrm{T}$ cells were from C57BL/6 (Fig. 1A) or from $\mathrm{CD}^{-1-}$ mice (Fig. 1B). The suppression by the wild type $T_{\text {reg }}$ cells was slightly less in Fig. 1B than in Fig. 1A, presumably due to increased proliferation of $\mathrm{CD}^{-l-}$ responder $\mathrm{T}$ cells. To be certain that the difference between $\mathrm{BL} / 6$ and $\mathrm{CD}^{-/-}$mice is not due to strain variations, since $\mathrm{CD}^{-/-}$mice were derived from $(\mathrm{BL} / 6 \times 129)$ mixed background, we also compared $\mathrm{T}_{\text {reg }}$ cells from $\mathrm{CD}^{-1-}$ mice back crossed to B6-Ly-5.1 mice for 12 generations. First, the suppression by either wild type or CD5 deficient $\mathrm{T}_{\text {reg }}$ was statistically significant $(p<0.05$ for wild type and $p<0.001$ for the CD5 knockout $\mathrm{T}_{\text {reg }}$ ) in comparison to the $\mathrm{T}$ effector proliferation response in the absence of $\mathrm{T}_{\text {reg }}$ cells. The $\mathrm{T}_{\text {reg }}$ cells from the knock-out strain were able to better inhibit the proliferation of responder T cells (65\%) when compared to that seen with the control strain $\mathrm{T}_{\text {reg }}$ cells $(p<0.03$ when comparing the suppression induced by wild type versus knockout) (Fig. 1C). This experiment with $\mathrm{CD}^{-1-}$ mice on a BL/6 background further confirms our finding that lack of CD5 is able to confer an enhanced suppressive property to the naturally 
arising $\mathrm{T}_{\text {reg }}$ cells. Similar increased potency of $\mathrm{CD}^{-1-} \mathrm{T}_{\text {reg }}$ cells was observed when they were isolated from the thymus (data not shown).

\section{Expression of CD4 and CD25 is similar in wild type and $C D 5^{-/-}$mice}

To determine if lack of CD5 affects the numbers or phenotype of $\mathrm{T}_{\text {reg }}$ cells, flow cytometric analysis of splenocytes, lymph nodes and thymocytes were performed. Fig. 2 shows the number of cells expressing CD4 and CD25/IL-2 R $\alpha$ chain and the density of the marker expression on splenocytes, lymph node cells, and thymocytes from wild type and $\mathrm{CD}^{-/-}$mice. Lack of CD5 expression on the $\mathrm{CD} 4^{+} \mathrm{T}$ cells did not affect either the number or density of the marker expression on the $\mathrm{CD} 4^{+} \mathrm{CD} 25^{+} \mathrm{T}_{\text {reg }}$ cells in the $\mathrm{CD}^{-1-}$ mice. Similar results were obtained with thymocytes. This suggests that CD5 may not have a role in the development of $\mathrm{T}_{\text {reg }}$ cells and subsequent maintenance of these cells in the periphery.

\section{Suppressive effects of $\mathrm{CD}^{+} \mathrm{CD}^{+} 5^{+} \mathrm{T}_{\text {reg }}$ cells from $\mathrm{CD}^{-/-}$mice are cell contact dependent}

The suppressive function of $\mathrm{CD} 4^{+} \mathrm{CD} 25^{+} \mathrm{T}_{\text {reg }}$ cells may be elicited via secretion of soluble factor(s) or require $\mathrm{T}_{\text {reg }}$-responder cell physical contact. Cell contact has been found to be an essential requirement for wild type $\mathrm{CD} 4^{+} \mathrm{CD} 25^{+} \mathrm{T}_{\text {reg }}$ cells to suppress the in vitro proliferation of effector T cells. Such a requirement for cell contact has not been shown for in vivo effectiveness of $\mathrm{T}_{\text {reg }}$ cells. $\mathrm{T}_{\text {reg }}$ cells were separated from $\mathrm{CD} 4^{+} \mathrm{CD}_{25}{ }^{-}$responder $\mathrm{T}$ cells in culture by inserting a Transwell which allows exchange of macromolecules but not cells. When $\mathrm{T}_{\text {reg }}$ cells were incubated along with the responder $\mathrm{T}$ cells in the lower compartment, there was a dramatic reduction ( 3 fold) in the proliferation which reflects what is seen in a 96 well coculture system. However, when the $\mathrm{T}_{\text {reg }}$ cells were separated from the responder $\mathrm{T}$ cells in a 24 well plate with a Transwell insert, proliferative response was significantly increased compared to the $\mathrm{T}_{\text {reg }}$ cells in the same compartment (Fig. 3 ). This indicates that like the wild type $\mathrm{T}_{\text {reg }}$ cells, the $\mathrm{CD}^{-1-} \mathrm{T}_{\text {reg }}$ cells require cell contact with the responder $\mathrm{T}$ cells for them to inhibit the proliferative response. Since some suppression remained even in the transwell system, it is conceivable that both contact dependent and independent mechanisms may be involved in suppression.

\section{$\mathrm{CD4}^{+} \mathrm{CD25}^{+} \mathrm{T}_{\text {reg }}$ mediated suppression of $\mathrm{CD}^{+} \mathrm{CD}^{-} 5^{-} \mathrm{T}$ cell proliferation in $\mathrm{CD}^{-/-}$mice is GITR dependent}

GITR is known to be expressed by $\mathrm{CD} 4^{+} \mathrm{CD} 25^{+} \mathrm{T}_{\text {reg }}$ cells constitutively. GITR is also inducible on naïve $\mathrm{CD} 4^{+} \mathrm{T}$ cells activated via the TCR. When engaged by its ligand, GITR-L; GITR triggers NF- $\kappa \mathrm{B}$ activation and prevents in vitro suppression mediated by $\mathrm{T}_{\text {reg }}$ cells by enhancing IL-2 secretion by the responder T cells (36). We tested if the increased suppressive ability of $\mathrm{T}_{\text {reg }}$ cells is due to increased GITR expression and is GITR dependent. The results revealed that the cell surface expression of GITR on $\mathrm{T}_{\text {reg }}$ cells obtained from $\mathrm{CD}^{-/-}$mice in resting as well as activated state was similar to that in wild type mice (Fig. 4 and Table I).

Moreover, treatment with DTA-1 (anti-GITR antibody) prevented $\mathrm{T}_{\text {reg }}$ mediated suppression of the $\mathrm{CD} 4^{+} \mathrm{CD} 25^{-}$responder $\mathrm{T}$ cell proliferation (data not shown).

\section{Intracellular Foxp3 levels are almost similar in wild type and CD5 knock-out strains}

Forkhead/winged-helix protein Foxp 3 is critical for the development and function of regulatory $\mathrm{T}$ cells $(12,13,37)$. It is considered as the most specific marker to date to identify $\mathrm{CD}^{+}$ $\mathrm{CD} 25^{+} \mathrm{T}_{\text {reg }}$ cells. We measured the intracellular protein levels of Foxp3 by flow cytometry in thymus, spleen and lymph nodes. Although the $\mathrm{CD} 4{ }^{+} \mathrm{CD} 25^{+} \mathrm{T}_{\text {reg }}$ cells from $\mathrm{CD} 5^{-1-}$ mice are functionally more effective than those from wild type mice in suppressing the proliferation of $\mathrm{CD} 4^{+} \mathrm{CD} 25^{-}$responder T cells; intracellular levels of Foxp3 in $\mathrm{CD}^{-1-}$ mice were similar to wild type strains in primary as well as secondary lymphoid organs (Fig. 5A and Table II show comparison between $\mathrm{CD}^{-/-}$mice in $\mathrm{BL} / 6 \times 129 \mathrm{~F} 2$ mixed back ground to wild type BL/6 mice; 
Fig. 5B shows comparison between $\mathrm{CD}^{-1-}$ in B6-Ly 5.1 background to B6-Ly 5.1 wild type ). Since the cells from lymph nodes characterized in Figure 5 were both peripheral (inguinal, axillary, superficial cervical, mandibular) and mucosal (mesenteric) in origin, we next measured the expression of Foxp3 in mesenteric lymph node (MLN) cells alone. The \% $\mathrm{CD}^{+} \mathrm{T}$ cells expressing Foxp3 in wild type and $\mathrm{CD}^{-/-}$MLN were again not different from each other confirming the findings in Table II and figure 5 (Table III). Therefore, CD5 appears to affect the function but not the number of $\mathrm{T}_{\text {reg }}$ cells in the secondary lymphoid organs.

\section{$\mathrm{CD}^{+} \mathrm{CD}^{+} 5^{+} \mathrm{T}_{\text {reg }}$ cells from $\mathrm{CD}^{-/-}$thymocytes elicit a larger $\mathrm{Ca}^{2+}$ flux than wild type thymocytes in response to CD3 stimulation}

TCR engagement induces release of $\mathrm{Ca}^{2+}$ that is crucial for subsequent intracellular signaling events leading to activation of transcription factors, cell survival, cell proliferation and cytokine production. We utilized this principle to test whether the highly potent $\mathrm{T}_{\text {reg }}$ cells from the $\mathrm{CD}^{-/-}$mice have an activated status that is greater than the wild type $\mathrm{T}_{\text {reg }}$ cells. In order to determine this, thymocytes from $\mathrm{CD}^{-/-}$and wild type strains were cross-linked with biotinylated anti-CD3 antibody and treated with avidin to elicit $\mathrm{Ca}^{2+}$ mobilization. This generated a tremendous increase in the $\mathrm{Ca}^{2+}$ flux from the $\mathrm{CD} 4^{+} \mathrm{CD} 25^{-} \mathrm{T}$ cell population in wild type as well as $\mathrm{CD}^{-1-}$ thymocytes (data not shown). When gated on the $\mathrm{CD} 4^{+} \mathrm{CD} 25^{+}$ $\mathrm{T}_{\text {reg }}$ cells (using $\mathrm{CD} 8$ to negatively gate on $\mathrm{CD} 4^{+} \mathrm{CD} 8^{-}$cells), the magnitude of $\mathrm{Ca}^{2+}$ response obtained was very modest compared to the responder $\mathrm{CD} 4^{+} \mathrm{CD} 25^{-} \mathrm{T}$ cells but was highly reproducible (Fig. 6A). Interestingly, $\mathrm{Ca}^{2+}$ flux generated by the $\mathrm{CD}^{-1-} \mathrm{T}_{\text {reg }}$ cells was consistently elevated in magnitude than that from the wild type $\mathrm{T}_{\text {reg }}$ cells indicating that the activation status of $\mathrm{CD5}^{-1-} \mathrm{T}_{\text {reg }}$ cells is higher than the wild type $\mathrm{T}_{\text {reg }}$ cells. Co-cross-linking TCR with antibodies to CD3 and co-stimulatory molecules CD4 and CD28 also generated a better $\mathrm{Ca}^{2+}$ response than with anti-CD3 alone in the $\mathrm{T}_{\text {reg }}$ cells (Fig. 6B). This $\mathrm{Ca}^{2+}$ flux was again higher from the $\mathrm{CD}^{-/-} \mathrm{T}_{\text {reg }}$ cells. Cross-linking $\mathrm{CD} 4$ or $\mathrm{CD} 28$ by themselves did not elicit any increased $\mathrm{Ca}^{2+}$ response from the baseline levels (controls not shown). Thus, loss of CD5 on the $\mathrm{T}_{\text {reg }}$ cells is enabling these cells to generate stronger signals from TCR than the wild type $\mathrm{T}_{\text {reg }}$ cells. The responses with lymph node $\mathrm{T}_{\text {reg }}$ cells were smaller in magnitude but showed similar pattern (data not shown). Upon comparison, the suppressive ability of thymus derived $\mathrm{T}_{\text {reg }}$ cells from $\mathrm{CD5}^{-/-}$mice were more effective than those from wild type mice (data not shown) consistent with the findings from the $\mathrm{Ca}^{2+}$ flux data.

\section{Foxp3 mRNA expression is increased in the colon of $\mathrm{CD}^{-/-}$mice compared to WT}

Although the expression of intracellular Foxp3 protein was no different between $\mathrm{CD}^{-1-}$ and WT lymphoid tissues, it was of interest to determine if there was any difference in the periphery at the RNA level. Tissues from $\mathrm{CD}^{-/}$and WT mice were harvested and processed for mRNA extraction to be analyzed by reverse transcription PCR. In accordance with the intracellular flow data, there was no difference in expression of Foxp3 in lymph nodes or in the spleen (data not shown). However, when analyzing whole colon tissue, there was over a 3 fold increase in Foxp3 expression from $\mathrm{CD}^{-/-}$mice compared to WT (Fig. 7). Currently we do not know if this is due to increased numbers of $\mathrm{T}_{\text {reg }}$ cells or due to increased expression of Foxp3 per cell in the colon of the knockout mice.

\section{Dextran Sodium Sulfate (DSS) - induced colitis is less severe in $\mathrm{CD5^{-/ }}$ mice compared to wild type mice}

Because it was shown that $\mathrm{CD}^{-/-}$mice expressed higher levels of Foxp3 in the colon, we were interested to see if Foxp3 ${ }^{+} \mathrm{T}_{\text {reg }}$ cells from $\mathrm{CD}^{-/-}$mice could be more protective than WT in vivo. To test the effect of loss of CD5, we used an acute colitis model (32). C57BL/6 (WT) or $\mathrm{CD}^{-/-}$mice were given normal drinking water, or water containing $3 \%$ DSS (w/v) to induce acute colitis over 7 days. Supporting the concept that CD5 inhibits $\mathrm{T}_{\text {reg }}$ cell function, 
$\mathrm{CD}^{-1-}$ mice were delayed in their development of acute colitis in comparison to WT mice. Such a delay was observed in three separate experiments. Thus, as shown in Fig. 8A, WT mice began to show signs of disease activity by day 3 , whereas $\mathrm{CD}^{-1-}$ mice showed symptoms of colitis by day 5 as defined by disease activity index (described in Materials and Methods). Colon shortening, another indicator of colitis severity, was less in $\mathrm{CD}^{-1-}$ mice (loss of $27 \%$ length) compared to WT mice (loss of $40 \%$ length, $p<0.05$ ). Finally, when analyzing the colon histopathology scores at day $7, \mathrm{CD}^{-1-}$ mice showed significantly less disease compared to WT mice (Fig. 8B). Samples of the colon sections are shown in Fig. 8C. There were no differences in the colon structure between WT and $\mathrm{CD}^{-1-}$ mice that were given water. WT mice that were administered 3\% DSS showed severe inflammation in the mucosa with intense epithelial disruption and ulceration and almost total loss of the crypt glands and goblet cells. Colons from $\mathrm{CD}^{-/-}$colitis mice were much less affected. There was only mild inflammation, leaving most of the crypts and the epithelium intact.

Although innate cells are critical for colitis development in this model, it is likely that either cytokines such as IL-10, or TGF- $\beta$, and/or or ligands for negative signaling molecules such as CTLA-4/PD-1 expressed better by $\mathrm{CD}^{-1-} \mathrm{T}_{\text {reg }}$ cells inhibit innate cell activation accounting for reduced inflammation. When analyzing the colon for IL-10 and TGF- $\beta$ mRNA, there was no difference between $\mathrm{CD}^{-/-}$and WT mice in either the control or DSS-colitis mice (data not shown).

\section{Discussion}

$\mathrm{T}_{\text {reg }}$ function is known to be antigen dependent and involves TCR derived signals. Several previous studies have shown that CD5 can modulate TCR signals. In particular CD5 ${ }^{-1-}$ thymocytes are hyper-responsive to TCR cross-linking (24). In certain models of tolerance induction increased CD5 expression has been shown to be critical for T cell anergy (28). Also CD5 expression is modified by the affinity of the antigen - $\mathrm{T}$ cell receptor interaction leading to a model of "sensory adaptation" in which low responsiveness of T cells is associated with high CD5 density $(38,39)$. If CD5 also affects TCR signaling in $\mathrm{T}_{\text {reg }}$ cells in a similar manner, one would predict an increased effectiveness of $\mathrm{T}_{\text {reg }}$ cells in the absence of CD5, which was brought out well by the studies presented here. This negative regulatory effect of CD5 on $\mathrm{T}_{\text {reg }}$ cell function is consistent with the recent finding that increased cytotoxicity of tumor infiltrating lymphocytes is correlated with decreased CD5 expression (40).

However, the mechanisms of increased suppression in $\mathrm{CD}^{-1-} \mathrm{T}_{\text {reg }}$ cells are not yet well understood. Based on our studies it is unlikely that the increased suppression is due to increased numbers of $\mathrm{T}_{\text {reg }}$ cells in $\mathrm{CD}^{-/-}$mice or due to altered expression of CD4 or CD25 surface markers. In the in vitro culture system used here, the $\mathrm{CD}^{-/-} \mathrm{T}_{\text {reg }}$ cells behave like wild type $\mathrm{T}_{\text {reg }}$ cells in requiring cell-cell contact for efficient inhibition, suggesting that increased secretion of inhibitory cytokines is not the major cause of increased suppression in the absence of CD5. Since GITR expression was linked to delivery of suppressive signals by $\mathrm{T}_{\text {reg }}$ cells, we evaluated GITR expression. Although $\mathrm{CD}^{-/-} \mathrm{T}_{\text {reg }}$ cells required GITR to mediate suppression, they did not express increased levels of GITR in resting or activated state. Foxp3, the most $\mathrm{T}_{\text {reg }}$ specific marker, was expressed at similar levels in $\mathrm{T}_{\text {reg }}$ cells from several lymphoid organs in the presence and the absence of CD5.

Despite the well-established need for antigen recognition by TCR in $\mathrm{T}_{\text {reg }}$ cells, no TCR derived downstream signaling events have thus far been identified in $\mathrm{T}_{\text {reg }}$ cells. We are reporting here, for the first time, that the TCR in $\mathrm{T}_{\text {reg }}$ cells induces a small but significant calcium flux when cross-linked alone or together with CD4 and/or CD28. The response is very much less than in $\mathrm{CD} 4{ }^{+} \mathrm{CD} 25^{-} \mathrm{T}$ cells but is highly consistent. This small TCR derived $\mathrm{Ca}^{2+}$ response is significantly enhanced in the absence of CD5 suggesting that TCR generates better signals in 
$\mathrm{T}_{\text {reg }}$ cells in the absence of CD5 and thus may contribute to their greater effectiveness. A role for calcium elevation in $\mathrm{T}_{\text {reg }}$ function is supported by the finding that NFAT transcription factor is important for $\mathrm{T}_{\text {reg }}$ cell function (41). There are reports suggesting that an interaction between NFAT and Foxp3 is required for the effector function of $T_{\text {reg }}$ cells (42-45). Since calcium signaling leads to activation of NFAT transcription factor, CD5 may be involved in regulating the activity of Foxp3 via NFAT. Recent studies have identified several Foxp3 interacting proteins and targets such as NFAT and a cyclic AMP dependent phosphodiesterase among others which will have to be evaluated in our system as possible targets of CD5 regulation $(46,47)$.

This increased effectiveness of $\mathrm{T}_{\text {reg }}$ function is consistent with the recent findings in the model of experimentally induced allergic encephalitis, wherein $\mathrm{CD} 5^{-1}$ mice were found to be more resistant to experimental autoimmune encephalitis (EAE) induction (48).

Interestingly, it has been shown that EAE is also more difficult to induce in transgenic mice that express a CD5 molecule deficient in its interaction with casein kinase $2(48,49)$. The increased resistance to EAE has been interpreted to be due to reduced survival of effector $\mathrm{T}$ cells in these mice. In preliminary studies we observed that anti-DNA antibody production is reduced in transgenic mice that express DNA specific BCR crossed to CD5 knockout background. Based on our preliminary results, we propose that the reduced autoimmunity in the EAE model and in the anti-DNA transgenic mouse model is due to increased effectiveness of regulatory $\mathrm{T}$ cells in the absence of CD5 derived signals. This is supported by several papers demonstrating the importance of $\mathrm{nT}_{\text {reg }}$ numbers and function in the regulation of $\mathrm{EAE}$ (50, $51)$.

To test if loss of CD5 affects $\mathrm{T}_{\text {reg }}$ function in vivo, we evaluated an animal model of colitis in $\mathrm{CD}^{-1-}$ mice. In vivo, $\mathrm{T}_{\text {reg }}$ cells can play an important role by regulating inflammatory disorders. For instance, $T_{\text {reg }}$ cells appear to play a role in the prevention of Inflammatory Bowel Disease (IBD) and experimental murine colitis. $T_{\text {reg }}$ cells have been found in human lamina propria tissue in both inflamed and healthy states (52). In addition, peripheral $\mathrm{T}_{\text {reg }}$ cells are significantly lower in number from patients with active ulcerative colitis (UC), a form of IBD, than those from healthy patients (53). In accordance with this, $T_{\text {reg }}$ cells are essential for prevention and cure of experimental colitis in murine models (54). They are thought to provide protection at both the site of inflammation and systemically, as $\mathrm{T}_{\text {reg }}$ cells proliferate in the lamina propria, spleen, and mesenteric lymph nodes. We utilized an acute model of murine colitis to monitor the ability of $\mathrm{T}_{\text {reg }}$ cells to curtail the disease progression for a fixed period of 1 week. The addition of 3\% Dextran Sulfate Sodium (DSS) to drinking water causes a severe acute colitis during DSS administration. Although it is reported that DSS colitis can be induced in lymphocyte deficient SCID mice, Kim et al. have shown that lymphocytes are involved in the onset of DSS colitis by the fact that disease progression was slower in lymphocyte deficient Rag-1 KO mice compared to the wild type C57BL/6 mice (55-57). Furthermore, a chronic form of DSS induced colitis has been shown to have a T cell component (58). Hence it is conceivable that DSS induced colitis is modulated more effectively by CD5 deficient $\mathrm{T}_{\text {reg }}$ cells.

Our findings in this DSS induced colitis model are in agreement with the in vitro studies which show that CD5 inhibits $T_{\text {reg }}$ function. Specifically, we found that the mice which lack CD5 expression were better able to resist colitis induction when induced by DSS. In each parameter of disease activity measured, colitis was less severe in $\mathrm{CD}^{-/}{ }^{-}$mice compared to WT.

$\mathrm{CD}^{-1-}$ mice showed delayed kinetics of disease onset, less colon shortening, and less severe histopathology compared to WT colitis mice (Fig. 8). This reinforces the idea of CD5 playing a crucial role in the initial activation of $\mathrm{T}_{\text {reg }}$ cells in a negative manner. Our observation that colonic cells from $\mathrm{CD}^{-1-}$ mice express more Foxp3 than those cells from wild type mice may indicate increased function or number of $\mathrm{T}_{\text {reg }}$ cells in the colon of $\mathrm{CD}^{-/-}$mice (Fig. 7). 
Researchers have shown in several colitis models that the $\mathrm{T}_{\text {reg }}$ mediated suppression of colitis is due to both IL-10 and TGF- $\beta(16,59)$. Surprisingly, this suppression may not be due to IL-10 or TGF- $\beta$, as mRNA levels were not increased in the colon of $\mathrm{CD}^{-1-}$ mice (data not shown). The mechanism of colitis suppression in $\mathrm{CD}^{-/-}$mice is at present unknown. However, our data are consistent with the concept that $\mathrm{T}_{\text {reg }}$ cells in $\mathrm{CD}^{-/-}$mice suppress inflammation more efficiently than wild type $\mathrm{T}_{\text {reg }}$ cells. Recently, Uhlig et al. have shown that Foxp3 ${ }^{+} \mathrm{CD}^{+}$ $\mathrm{CD} 25^{+} \mathrm{T}_{\text {reg }}$ cells are located in the lymphoid tissues of the gut as well as in the lamina propria under normal and inflamed conditions (60). Since $\mathrm{T}_{\text {reg }}$ cells are present in the lamina propria constitutively, the authors suggested a possible role for these cells in intestinal homeostasis (50). These findings fit with our data; namely that $\mathrm{CD}^{-1-} \mathrm{T}_{\text {reg }}$ cells may have an increased ability to control intestinal homeostasis, as the kinetics of colitis onset was increased in WT mice.

Do other cells such as CD8 T cells and B-1 B cells that express CD5 have a role in the increased resistance of $\mathrm{CD}^{-/-}$mice to colitis induction? B-1 B cells appear to suppress colitis since their absence in the Gai2 knockout mice makes them susceptible to inflammatory bowel disease (61). Control of colitis by B cells has been proposed to be due to IL-10 secretion from B-1 cells (62). Our preliminary studies show that B-1 cell production of IL-10 is not increased in the absence of CD5 (Sindhava et al unpublished results). In fact some in vitro studies suggest that CD5 is required for IL-10 production by B-1 cells (63). Hence increased activity of B-1 cells is not likely the reason for the colitis resistance in the CD5 null mice. Thus far there is no evidence for CD5 mediated regulation of CD8 T cell function but it cannot be ruled out at this stage and $\mathrm{CD}^{+} \mathrm{T}_{\text {reg }}$ have been shown to regulate colitis (64). It is interesting that a double knockout for CD5 and the TCR $\beta$ molecules resulted in increased chronic colitis compared to TCR $\beta$ KO alone, suggesting in this case, when $\alpha \beta$ T cells are absent, the presence of the CD5 molecule helps to suppress colitis (65). The role of CD5 in $\gamma \delta \mathrm{T}$ cells has not yet been studied. Regardless of the mechanism of DSS-induced colitis suppression in $\mathrm{CD}^{-/-}$mice, this study further enunciates the principle that the $\mathrm{CD} 4^{+} \mathrm{CD} 25^{+} \mathrm{T}_{\text {reg }}$ cells have the ability to keep colitis in check and by blocking $\mathrm{CD} 5$ (or $\mathrm{CD}^{-/}$) the severity of the disease is reduced. Thus antagonists of CD5 may be useful to ameliorate the severity of inflammatory bowel diseases.

\section{Acknowledgements}

This research has been supported by NIH grants to SB and CR. We thank Mr. Darrell Robertson for his expert technical assistance and Ms. Jennifer Strange and Greg Bowman for their assistance with flow cytometry.

\section{References}

1. Bluestone JA, Abbas AK. Natural versus adaptive regulatory T cells. Nat Rev Immunol 2003;3:253257. [PubMed: 12658273]

2. Izcue A, Powrie F. Special regulatory T-cell review: regulatory T cells and the intestinal tract patrolling the frontier. Immunology 2008;123:6-10. [PubMed: 18154611]

3. Dario V. How many mechanisms do regulatory T cells need? Eur J Immunol 2008;38:908-911. [PubMed: 18395857]

4. Thornton AM, Shevach EM. CD4+CD25+ immunoregulatory T cells suppress polyclonal T cell activation in vitro by inhibiting interleukin 2 production. J Exp Med 1998;188:287-296. [PubMed: 9670041]

5. Shimizu J, Yamazaki S, Takahashi T, Ishida Y, Sakaguchi S. Stimulation of CD $25^{+} \mathrm{CD} 4^{+}$regulatory T cells through GITR breaks immunological self-tolerance. Nat Immunol 2002;3:135-142. [PubMed: 11812990]

6. Stephens GL, McHugh RS, Whitters MJ, Young DA, Luxenberg D, Carreno BM, Collins M, Shevach EM. Engagement of glucocorticoid-induced TNFR family-related receptor on effector T cells by its ligand mediates resistance to suppression by CD4+CD25+ T cells. J Immunol 2004;173:5008-5020. [PubMed: 15470044] 
7. McHugh RS, Whitters MJ, Piccirillo CA, Young DA, Shevach EM, Collins M, Byrne MC. CD4(+) CD25(+) immunoregulatory T cells: gene expression analysis reveals a functional role for the glucocorticoid-induced TNF receptor. Immunity 2002;16:311-323. [PubMed: 11869690]

8. Pandiyan P, Zheng L, Ishihara S, Reed J, Lenardo MJ. CD4+CD25+Foxp3+ regulatory T cells induce cytokine deprivation-mediated apoptosis of effector CD4+ T cells. Nat Immunol 2007;8:1353-1362. [PubMed: 17982458]

9. Bruder D, Probst-Kepper M, Westendorf AM, Geffers R, Beissert S, Loser K, von Boehmer H, Buer J, Hansen W. Neuropilin-1: a surface marker of regulatory T cells. Eur J Immunol 2004;34:623-630. [PubMed: 14991591]

10. Choi BK, Bae JS, Choi EM, Kang WJ, Sakaguchi S, Vinay DS, Kwon BS. 4-1BB-dependent inhibition of immunosuppression by activated CD4+CD25+T cells. J Leukoc Biol 2004;75:785-791. [PubMed: 14694186]

11. Hori S, Nomura T, Sakaguchi S. Control of regulatory T cell development by the transcription factor Foxp3. Science 2003;299:1057-1061. [PubMed: 12522256]

12. Fontenot JD, Gavin MA, Rudensky AY. Foxp3 programs the development and function of CD4 +CD25+ regulatory T cells. Nat Immunol 2003;4:330-336. [PubMed: 12612578]

13. Khattri R, Cox T, Yasayko SA, Ramsdell F. An essential role for Scurfin in CD4+CD25+ T regulatory cells. Nat Immunol 2003;4:337-342. [PubMed: 12612581]

14. Fontenot JD, Rasmussen JP, Williams LM, Dooley JL, Farr AG, Rudensky AY. Regulatory T cell lineage specification by the forkhead transcription factor foxp3. Immunity 2005;22:329-341. [PubMed: 15780990]

15. Shohei H. Rethinking the molecular definition of regulatory T cells. Eur J Immunol 2008;38:928930. [PubMed: 18395863]

16. Powrie F, Carlino J, Leach MW, Mauze S, Coffman RL. A critical role for transforming growth factor-beta but not interleukin 4 in the suppression of T helper type 1-mediated colitis by CD45RB (low) CD4+ T cells. J Exp Med 1996;183:2669-2674. [PubMed: 8676088]

17. Liu H, Hu B, Xu D, Liew FY. CD4+CD25+ regulatory T cells cure murine colitis: the role of IL-10, TGF-beta, and CTLA4. J Immunol 2003;171:5012-5017. [PubMed: 14607897]

18. Chen W, Wahl SM. TGF- $\beta$ : the missing link in $\mathrm{CD} 4{ }^{+} \mathrm{CD} 25^{+}$regulatory T cell-mediated immunosuppression. Cytokine Growth Factor Rev 2003;14:85-89. [PubMed: 12651220]

19. Sutmuller RPM, Morgan ME, Netea MG, Grauer O, Adema GJ. Toll-like receptors on regulatory T cells: expanding immune regulation. Trends in Immunology 2006;27:387-393. [PubMed: 16814607]

20. Wang HY, Wang R-F. Regulatory T cells and cancer. Curr Opin Immunol 2007;19:217-223. [PubMed: 17306521]

21. van Eden W, Hauet-Broere F, Berlo S, Paul L, van der Zee R, de Kleer I, Prakken B, Taams L. Stress proteins as inducers and targets of regulatory T cells in arthritis. Int Rev Immunol 2005;24:181-197. [PubMed: 16036373]

22. Chen X, Murakami T, Oppenheim JJ, Howard OM. Differential response of murine CD4+CD25+ and CD4+CD25- T cells to dexamethasone-induced cell death. Eur J Immunol 2004;34:859-869. [PubMed: 14991616]

23. Bikah G, Carey J, Ciallella JR, Tarakhovsky A, Bondada S. CD5-mediated negative regulation of antigen receptor-induced growth signals in B-1 B cells. Science 1996;274:1906-1909. [PubMed: 8943203]

24. Tarakhovsky A, Kanner SB, Hombach J, Ledbetter JA, Muller W, Killeen N, Rajewsky K. A role for CD5 in TCR-mediated signal transduction and thymocyte selection. Science 1995;269:535-537. [PubMed: 7542801]

25. Perez-Villar JJ, Whitney GS, Bowen MA, Hewgill DH, Aruffo AA, Kanner SB. CD5 negatively regulates the T-cell antigen receptor signal transduction pathway: involvement of SH2-containing phosphotyrosine phosphatase SHP-1. Mol Cell Biol 1999;19:2903-2912. [PubMed: 10082557]

26. Azzam HS, DeJarnette JB, Huang K, Emmons R, Park C-S, Sommers CL, El-Khoury D, Shores EW, Love PE. Fine Tuning of TCR Signaling by CD5. J Immunol 2001;166:5464-5472. [PubMed: 11313384]

27. Stamou P, de Jersey J, Carmignac D, Mamalaki C, Kioussis D, Stockinger B. Chronic exposure to low levels of antigen in the periphery causes reversible functional impairment correlating with 
changes in CD5 levels in monoclonal CD8 T cells. J Immunol 2003;171:1278-1284. [PubMed: 12874216]

28. Hawiger D, Masilamani RF, Bettelli E, Kuchroo VK, Nussenzweig MC. Immunological unresponsiveness characterized by increased expression of CD5 on peripheral T cells induced by dendritic cells in vivo. Immunity 2004;20:695-705. [PubMed: 15189735]

29. Thornton AM, Shevach EM. Suppressor effector function of CD4+CD25+ immunoregulatory T cells is antigen nonspecific. J Immunol 2000;164:183-190. [PubMed: 10605010]

30. Apostolou I, Sarukhan A, Klein L, von Boehmer H. Origin of regulatory T cells with known specificity for antigen. Nat Immunol 2002;3:756-763. [PubMed: 12089509]

31. Sen G, Wu HJ, Bikah G, Venkataraman C, Robertson DA, Snow EC, Bondada S. Defective CD19dependent signaling in B-1a and B-1b B lymphocyte subpopulations. Mol Immunol 2002;39:57-68. [PubMed: 12213328]

32. Murthy SN, Cooper HS, Shim H, Shah RS, Ibrahim SA, Sedergran DJ. Treatment of dextran sulfate sodium-induced murine colitis by intracolonic cyclosporin. Dig Dis Sci 1993;38:1722-1734. [PubMed: 8359087]

33. Qualls JE, Kaplan AM, van Rooijen N, Cohen DA. Suppression of experimental colitis by intestinal mononuclear phagocytes. J Leukoc Biol 2006;80:802-815. [PubMed: 16888083]

34. Berg DJ, Davidson N, Kuhn R, Muller W, Menon S, Holland G, Thompson-Snipes L, Leach MW, Rennick D. Enterocolitis and colon cancer in interleukin-10-deficient mice are associated with aberrant cytokine production and CD4(+) TH1-like responses. J Clin Invest 1996;98:1010-1020. [PubMed: 8770874]

35. Sen G, Bikah G, Venkataraman C, Bondada S. Negative regulation of antigen receptor-mediated signaling by constitutive association of CD5 with the SHP-1 protein tyrosine phosphatase in B-1 B cells. Eur J Immunol 1999;29:3319-3328. [PubMed: 10540344]

36. Ji HB, Liao G, Faubion WA, Abadia-Molina AC, Cozzo C, Laroux FS, Caton A, Terhorst C. Cutting edge: the natural ligand for glucocorticoid-induced TNF receptor-related protein abrogates regulatory T cell suppression. J Immunol 2004;172:5823-5827. [PubMed: 15128759]

37. Kim JM, Rudensky A. The role of the transcription factor Foxp 3 in the development of regulatory $\mathrm{T}$ cells. Immunol Rev 2006;212:86-98. [PubMed: 16903908]

38. Smith K, Seddon B, Purbhoo MA, Zamoyska R, Fisher AG, Merkenschlager M. Sensory Adaptation in Naive Peripheral CD4 T Cells. J. Exp. Med 2001;194:1253-1262. [PubMed: 11696591]

39. Bhandoola A, Bosselut R, Yu Q, Cowan ML, Feigenbaum L, Love PE, Singer A. CD5-mediated inhibition of TCR signaling during intrathymic selection and development does not require the CD5 extracellular domain. Eur J Immunol 2002;32:1811-1817. [PubMed: 12115665]

40. Dorothee G, Vergnon I, El Hage F, Chansac BLM, Ferrand V, Lecluse Y, Opolon P, Chouaib S, Bismuth G, Mami-Chouaib F. In Situ Sensory Adaptation of Tumor-Infiltrating T Lymphocytes to Peptide-MHC Levels Elicits Strong Antitumor Reactivity. J Immunol 2005;174:6888-6897. [PubMed: 15905531]

41. Bopp T, Palmetshofer A, Serfling E, Heib V, Schmitt S, Richter C, Klein M, Schild H, Schmitt E, Stassen M. NFATc2 and NFATc3 transcription factors play a crucial role in suppression of CD4+ T lymphocytes by CD4+ CD25+ regulatory T cells. J. Exp. Med 2005;201:181-187. [PubMed: 15657288]

42. Wu Y, Borde M, Heissmeyer V, Feuerer M, Lapan AD, Stroud JC, Bates DL, Guo L, Han A, Ziegler SF, Mathis D, Benoist C, Chen L, Rao A. FOXP3 controls regulatory T cell function through cooperation with NFAT. Cell 2006;126:375-387. [PubMed: 16873067]

43. Rudensky AY, Gavin M, Zheng Y. FOXP3 and NFAT: partners in tolerance. Cell 2006;126:253256. [PubMed: 16873058]

44. Bettelli E, Dastrange M, Oukka M. Foxp3 interacts with nuclear factor of activated T cells and NFkappa B to repress cytokine gene expression and effector functions of Thelper cells. Proc Natl Acad Sci U S A 2005;102:5138-5143. [PubMed: 15790681]

45. Sumpter TL, Payne KK, Wilkes DS. Regulation of the NFAT pathway discriminates CD4+CD25+ regulatory T cells from CD4+CD25- helper T cells. J Leukoc Biol 2008;83:708-717. [PubMed: 18032693] 
46. Marson A, Kretschmer K, Frampton GM, Jacobsen ES, Polansky JK, MacIsaac KD, Levine SS, Fraenkel E, von Boehmer H, Young RA. Foxp3 occupancy and regulation of key target genes during T-cell stimulation. Nature 2007;445:931-935. [PubMed: 17237765]

47. Zheng Y, Josefowicz SZ, Kas A, Chu TT, Gavin MA, Rudensky AY. Genome-wide analysis of Foxp3 target genes in developing and mature regulatory T cells. Nature 2007;445:936-940. [PubMed: 17237761]

48. Axtell RC, Webb MS, Barnum SR, Raman C. Cutting Edge: Critical Role for CD5 in Experimental Autoimmune Encephalomyelitis: Inhibition of Engagement Reverses Disease in Mice. J Immunol 2004;173:2928-2932. [PubMed: 15322150]

49. Axtell RC, Xu L, Barnum SR, Raman C. CD5-CK2 Binding/Activation-Deficient Mice Are Resistant to Experimental Autoimmune Encephalomyelitis: Protection Is Associated with Diminished Populations of IL-17-Expressing T Cells in the Central Nervous System. J Immunol 2006;177:85428549. [PubMed: 17142752]

50. Reddy J, Waldner H, Zhang X, Illes Z, Wucherpfennig KW, Sobel RA, Kuchroo VK. Cutting edge: $\mathrm{CD} 4+\mathrm{CD} 25+$ regulatory $\mathrm{T}$ cells contribute to gender differences in susceptibility to experimental autoimmune encephalomyelitis. J Immunol 2005;175:5591-5595. [PubMed: 16237044]

51. Yu P, Gregg RK, Bell JJ, Ellis JS, Divekar R, Lee HH, Jain R, Waldner H, Hardaway JC, Collins M, Kuchroo VK, Zaghouani H. Specific T regulatory cells display broad suppressive functions against experimental allergic encephalomyelitis upon activation with cognate antigen. J Immunol 2005;174:6772-6780. [PubMed: 15905518]

52. Makita S, Kanai T, Oshima S, Uraushihara K, Totsuka T, Sawada T, Nakamura T, Koganei K, Fukushima T, Watanabe M. CD4+CD25bright T cells in human intestinal lamina propria as regulatory cells. J Immunol 2004;173:3119-3130. [PubMed: 15322172]

53. Takahashi M, Nakamura K, Honda K, Kitamura Y, Mizutani T, Araki Y, Kabemura T, Chijiiwa Y, Harada N, Nawata $\mathrm{H}$. An inverse correlation of human peripheral blood regulatory $\mathrm{T}$ cell frequency with the disease activity of ulcerative colitis. Dig Dis Sci 2006;51:677-686. [PubMed: 16614988]

54. Coombes JL, Robinson NJ, Maloy KJ, Uhlig HH, Powrie F. Regulatory T cells and intestinal homeostasis. Immunol Rev 2005;204:184-194. [PubMed: 15790359]

55. Axelsson LG, Landstrom E, Goldschmidt TJ, Gronberg A, Bylund-Fellenius AC. Dextran sulfate sodium (DSS) induced experimental colitis in immunodeficient mice: effects in CD4(+) -cell depleted, athymic and NK-cell depleted SCID mice. Inflamm Res 1996;45:181-191. [PubMed: 8741008]

56. Dieleman LA, Ridwan BU, Tennyson GS, Beagley KW, Bucy RP, Elson CO. Dextran sulfate sodiuminduced colitis occurs in severe combined immunodeficient mice. Gastroenterology 1994;107:16431652. [PubMed: 7958674]

57. Kim TW, Seo JN, Suh YH, Park HJ, Kim JH, Kim JY, Oh KI. Involvement of lymphocytes in dextran sulfate sodium-induced experimental colitis. World J Gastroenterol 2006;12:302-305. [PubMed: 16482634]

58. Shintani N, Nakajima T, Okamoto T, Kondo T, Nakamura N, Mayumi T. Involvement of CD4+ T cells in the development of dextran sulfate sodium-induced experimental colitis and suppressive effect of IgG on their action. Gen Pharmacol 1998;31:477-481. [PubMed: 9703223]

59. Asseman C, Mauze S, Leach MW, Coffman RL, Powrie F. An essential role for interleukin 10 in the function of regulatory T cells that inhibit intestinal inflammation. J Exp Med 1999;190:995-1004. [PubMed: 10510089]

60. Uhlig HH, Coombes J, Mottet C, Izcue A, Thompson C, Fanger A, Tannapfel A, Fontenot JD, Ramsdell F, Powrie F. Characterization of Foxp3+CD4+CD25+ and IL-10-Secreting CD4+CD25+ T Cells during Cure of Colitis. J Immunol 2006;177:5852-5860. [PubMed: 17056509]

61. Dalwadi H, Wei B, Schrage M, Su TT, Rawlings DJ, Braun J. B Cell Developmental Requirement for the G\{alpha\}i2 Gene. J Immunol 2003;170:1707-1715. [PubMed: 12574334]

62. Mizoguchi A, Mizoguchi E, Takedatsu H, Blumberg RS, Bhan AK. Chronic Intestinal Inflammatory Condition Generates IL-10-Producing Regulatory B Cell Subset Characterized by CD1d Upregulation. Immunity 2002;16:219-230. [PubMed: 11869683] 
63. Gary-Gouy H, Harriague J, Bismuth G, Platzer C, Schmitt C, Dalloul AH. Human CD5 promotes Bcell survival through stimulation of autocrine IL-10 production. Blood 2002;100:4537-4543. [PubMed: 12393419]

64. Menager-Marcq I, PomiE C, Romagnoli P, van Meerwijk JPM. CD8+CD28- Regulatory T Lymphocytes Prevent Experimental Inflammatory Bowel Disease in Mice. Gastroenterology 2006;131:1775-1785. [PubMed: 17087950]

65. Mizoguchi A, Mizoguchi E, de Jong YP, Takedatsu H, Preffer FI, Terhorst C, Bhan AK. Role of the CD5 molecule on TCR gammadelta T cell-mediated immune functions: development of germinal centers and chronic intestinal inflammation. Int Immunol 2003;15:97-108. [PubMed: 12502730] 


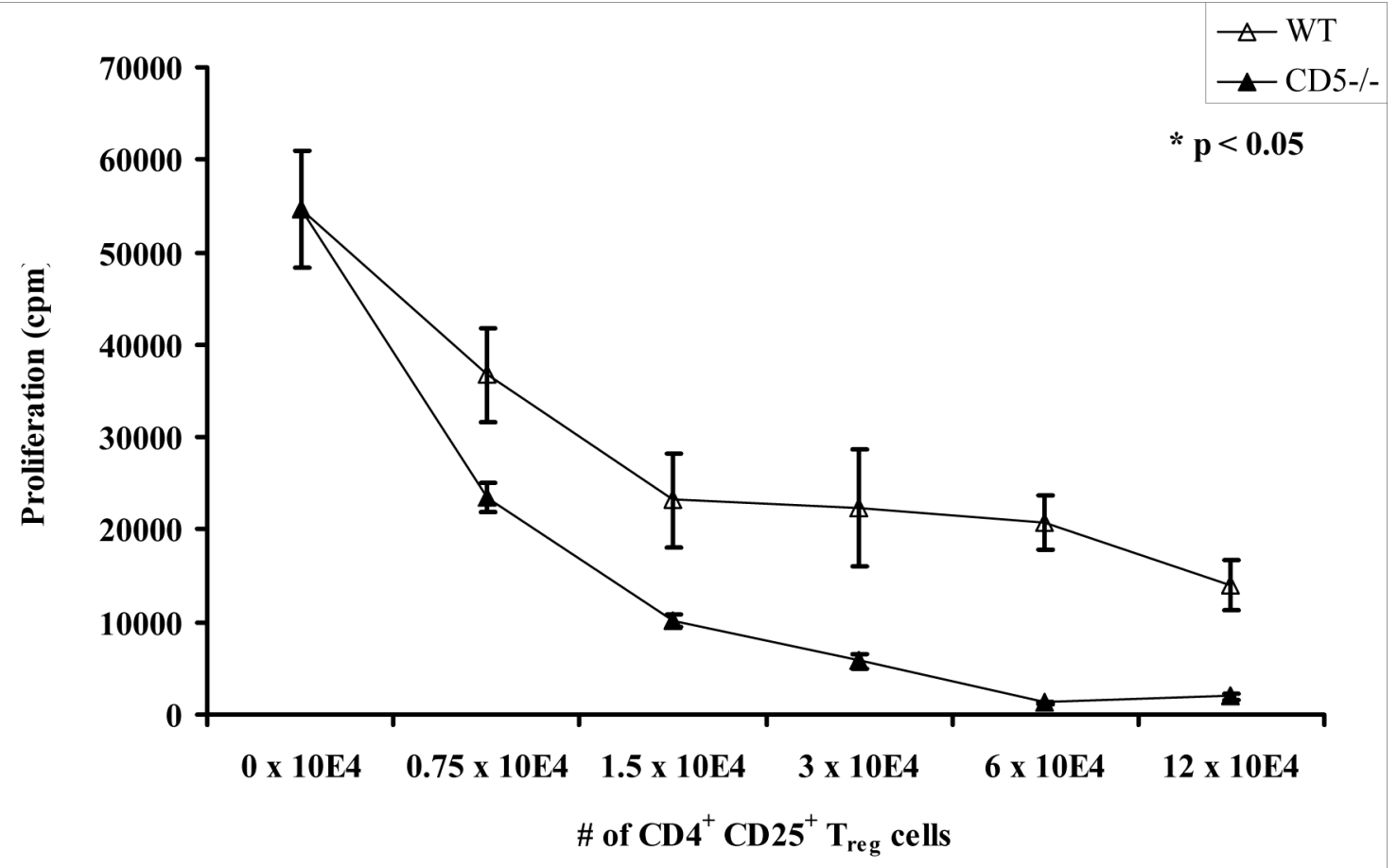

圆 WT Treg

$\square$ CD5-/- Treg

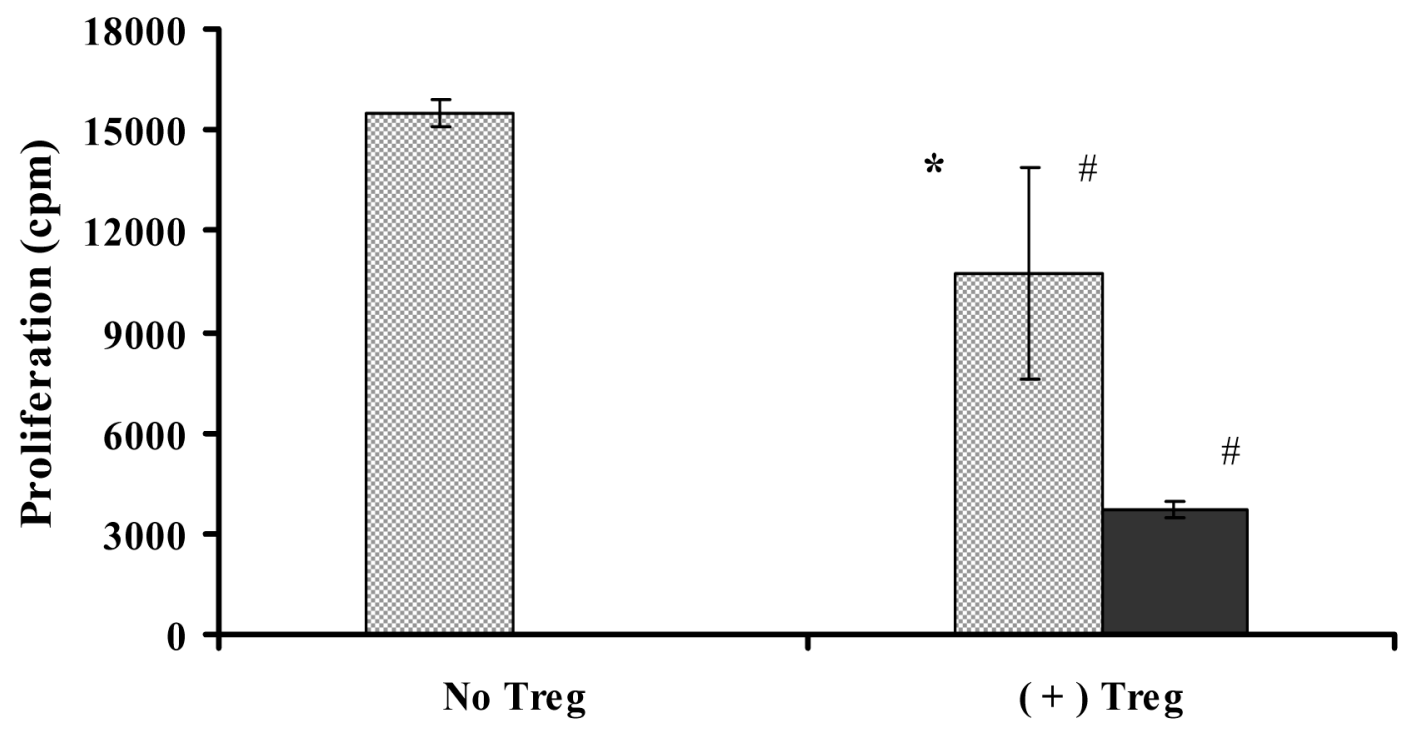

$T_{\text {reg }}:$ Responder cell ratio $=2: 1$ 


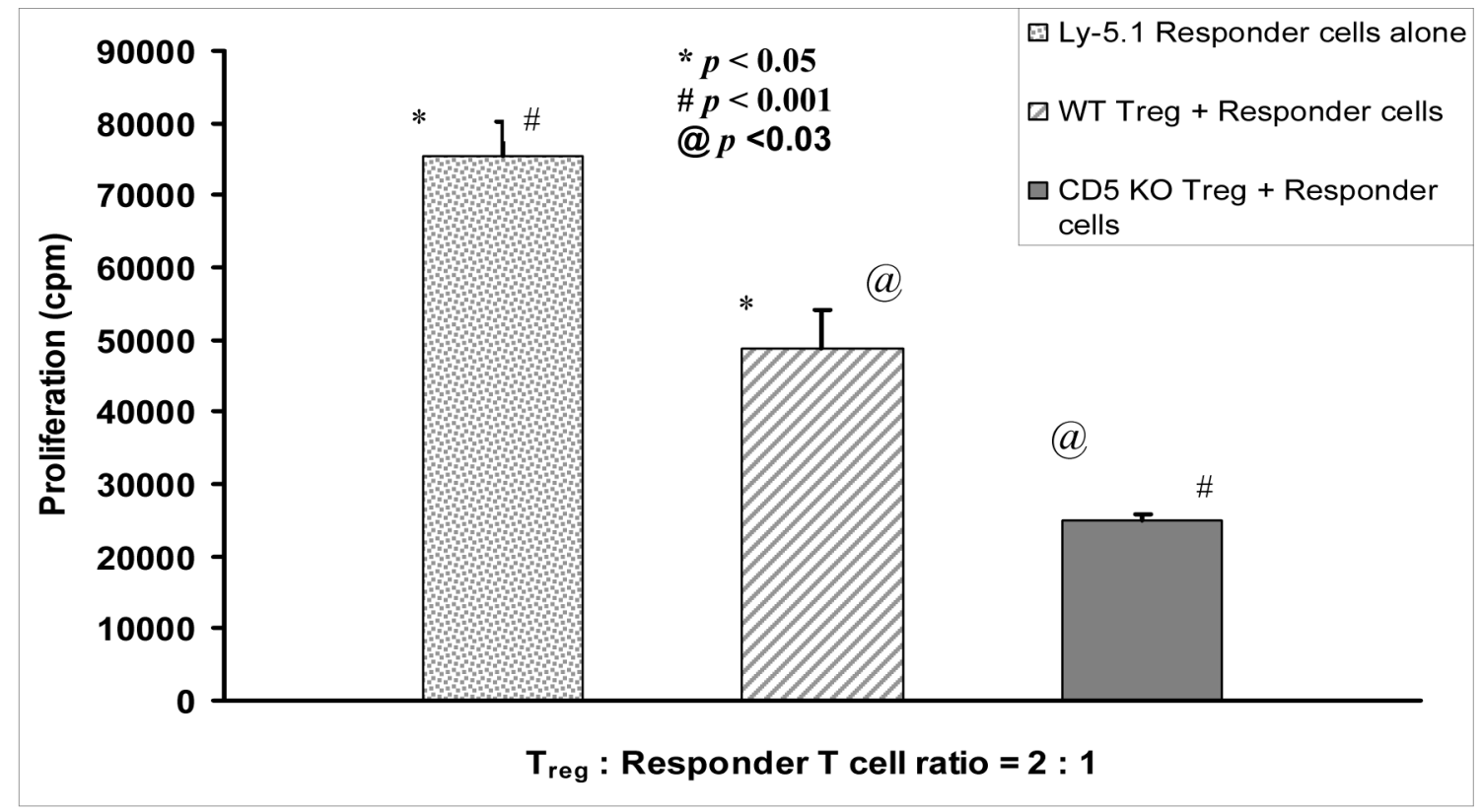

Figure 1. $\mathrm{CD}^{+} \mathrm{CD}^{+} \mathrm{T}_{\text {reg }}$ cells from $\mathrm{CD5}^{-/-}$mice are more potent than those from wild type mice in suppressing in vitro proliferation of $\mathrm{CD4}^{+} \mathrm{CD25}^{-}$responder $\mathrm{T}$ cells

(A) $6 \times 10^{4} \mathrm{CD}^{+} \mathrm{CD} 25^{-}$cells from C57BL/6 mice were stimulated with $10 \mu \mathrm{g} / \mathrm{ml}$ soluble anti-CD3 in presence of $6 \times 10^{4}$ accessory cells and varying numbers of CD4 ${ }^{+} \mathrm{CD} 25^{+} \mathrm{T}_{\text {reg }}$ cells from either 4 month old wild type (C57BL/6) or $\mathrm{CD}^{-1-}$ mice. Results are expressed as mean \pm SE of triplicate cultures. The difference in responses from wild type and knock out $\mathrm{T}_{\text {reg }}$ cells was significant $(* p<0.05)$ at each ratio of $\mathrm{T}_{\text {reg }}$ : responder $\mathrm{T}$ cell tested. Graph is a representative of one of four independent experiments.

(B) $6 \times 10^{4} \mathrm{CD}^{+} \mathrm{CD}^{2} 5^{-}$responder T cells from $\mathrm{CD}^{-1-}$ mice were cultured with $\mathrm{CD}^{-1-} \mathrm{APC}$ (antigen presenting cells) and anti-CD3 in the presence of $\mathrm{CD}^{+} \mathrm{CD} 25^{+} \mathrm{T}_{\text {reg }}$ cells from either wild type $\mathrm{C} 57 \mathrm{BL} / 6$ or $\mathrm{CD} 5^{-1-}$ mice. The cpm values obtained after $72 \mathrm{~h}$ culture represent mean \pm SE of triplicate wells. The graph shown is one of two experiments performed. Some of the SE bars are too small to be seen. * and \# indicate $p<0.05$.

(C) $6 \times 10^{4} \mathrm{CD}^{+} \mathrm{CD}^{2} 5^{-}$responder T cells from B6.Ly 5.1 mice were cultured with $\mathrm{CD}^{-1-}$ $\mathrm{APC}$ and anti-CD3 in the presence of $\mathrm{CD} 4^{+} \mathrm{CD} 25^{+} \mathrm{T}_{\text {reg }}$ cells from either wild type B6-Ly5.1 or B6-Ly5.1.CD5 ${ }^{-1-}$ mice. The cpm values obtained after $72 \mathrm{~h}$ culture represent mean $\pm \mathrm{SE}$ of triplicate wells. The differences in responses with wild type and $\mathrm{CD} 5^{-/-} \mathrm{T}_{\text {reg }}$ cells are statistically significant as indicated. 


\section{Spleen}

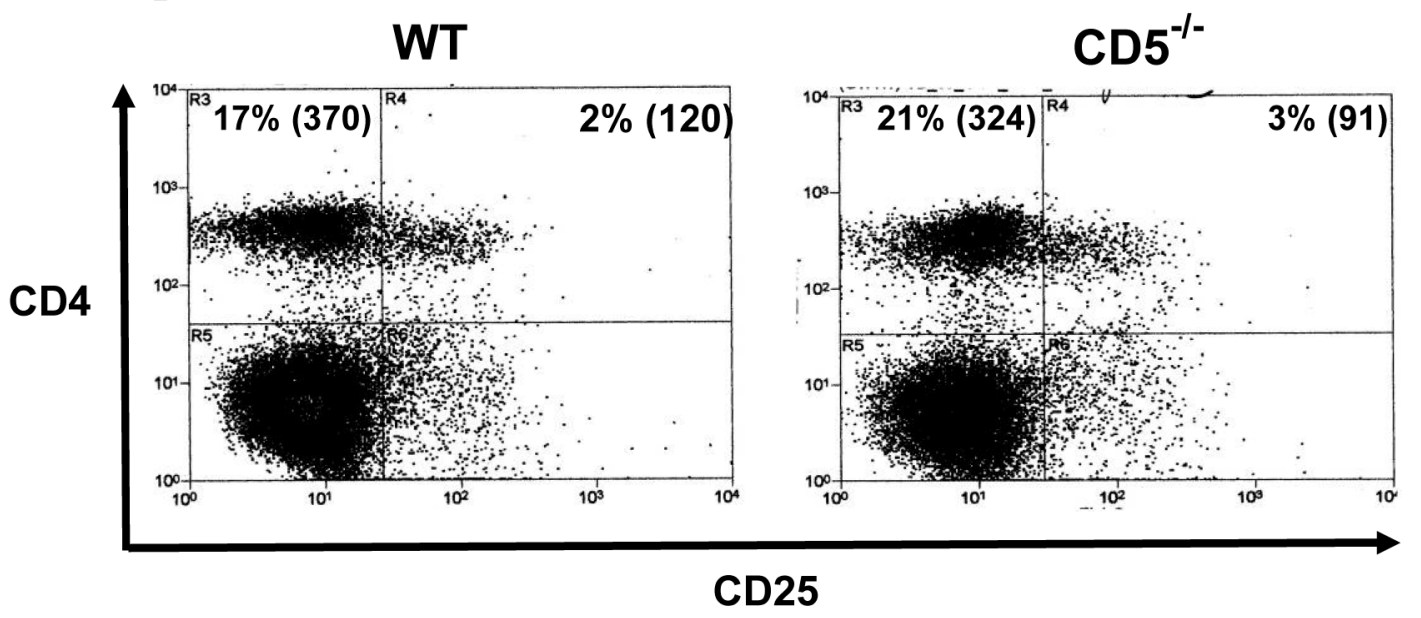

\section{Lymph Node}

WT

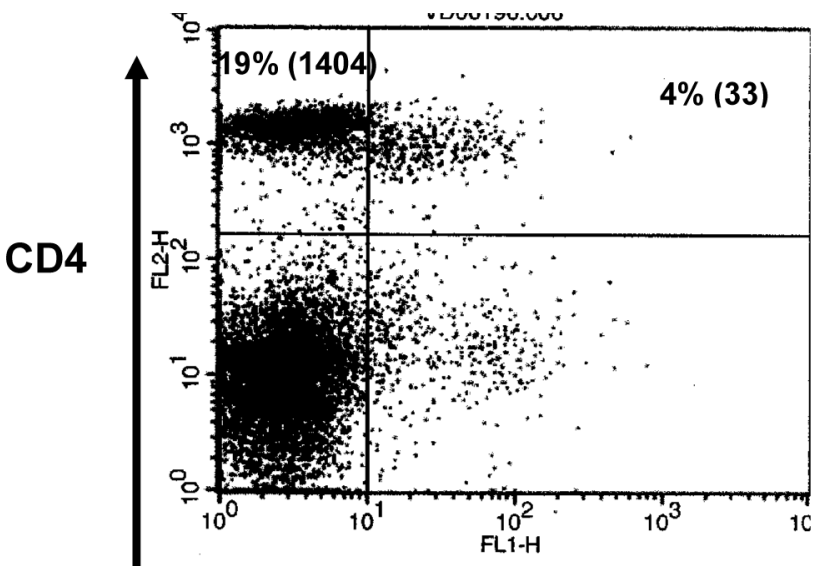

$\mathrm{CD}^{-1-}$






\section{Thymus}

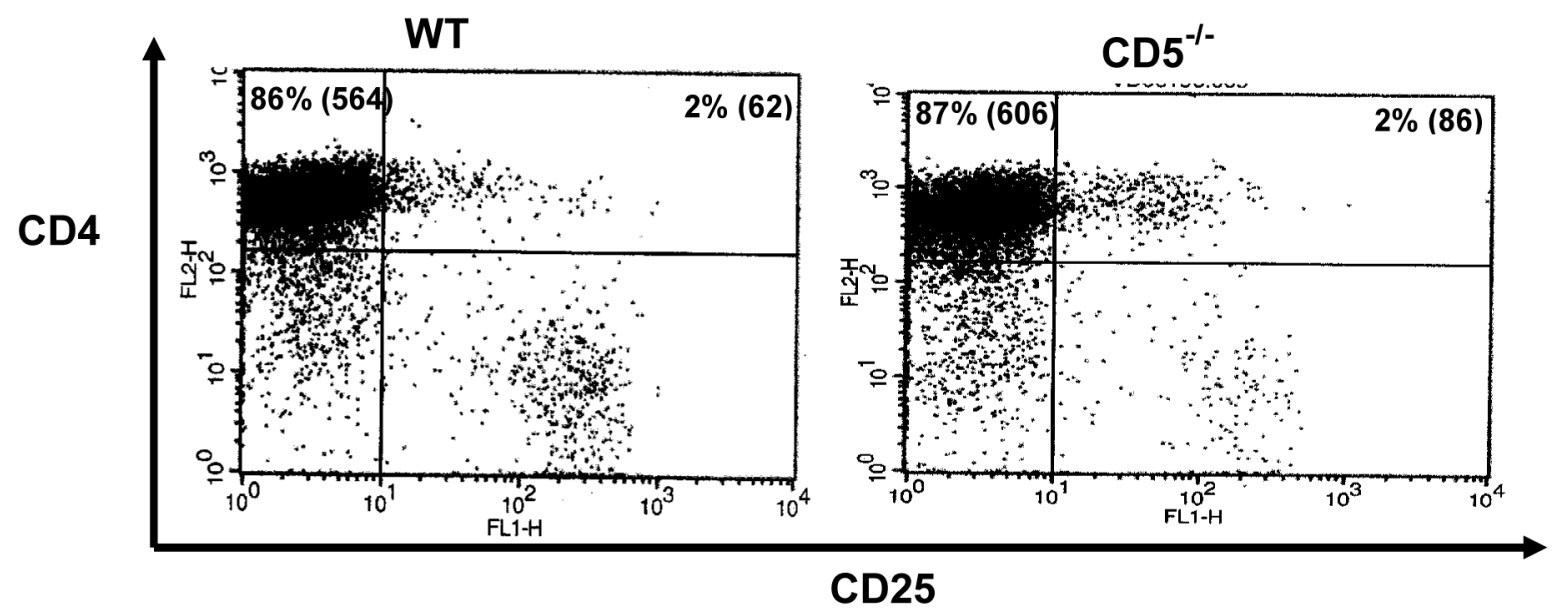

Figure 2. Cell surface expression of CD4 and CD25 is similar in wild type and $\mathrm{CD5}^{-/-}$mice Splenocytes, lymph node cells and thymocytes from 4 month old wild type C57BL/6 or $\mathrm{CD}^{-1-}$ mice were stained for cell surface expression of CD4 and CD25. The percent positive spleen cells in viable lymphocyte gate and the mean fluorescence intensity (MFI) (in parenthesis) are shown within each gated region of the dot plot. This is representative of one of five independent analyses each involving 3-5 mice. 


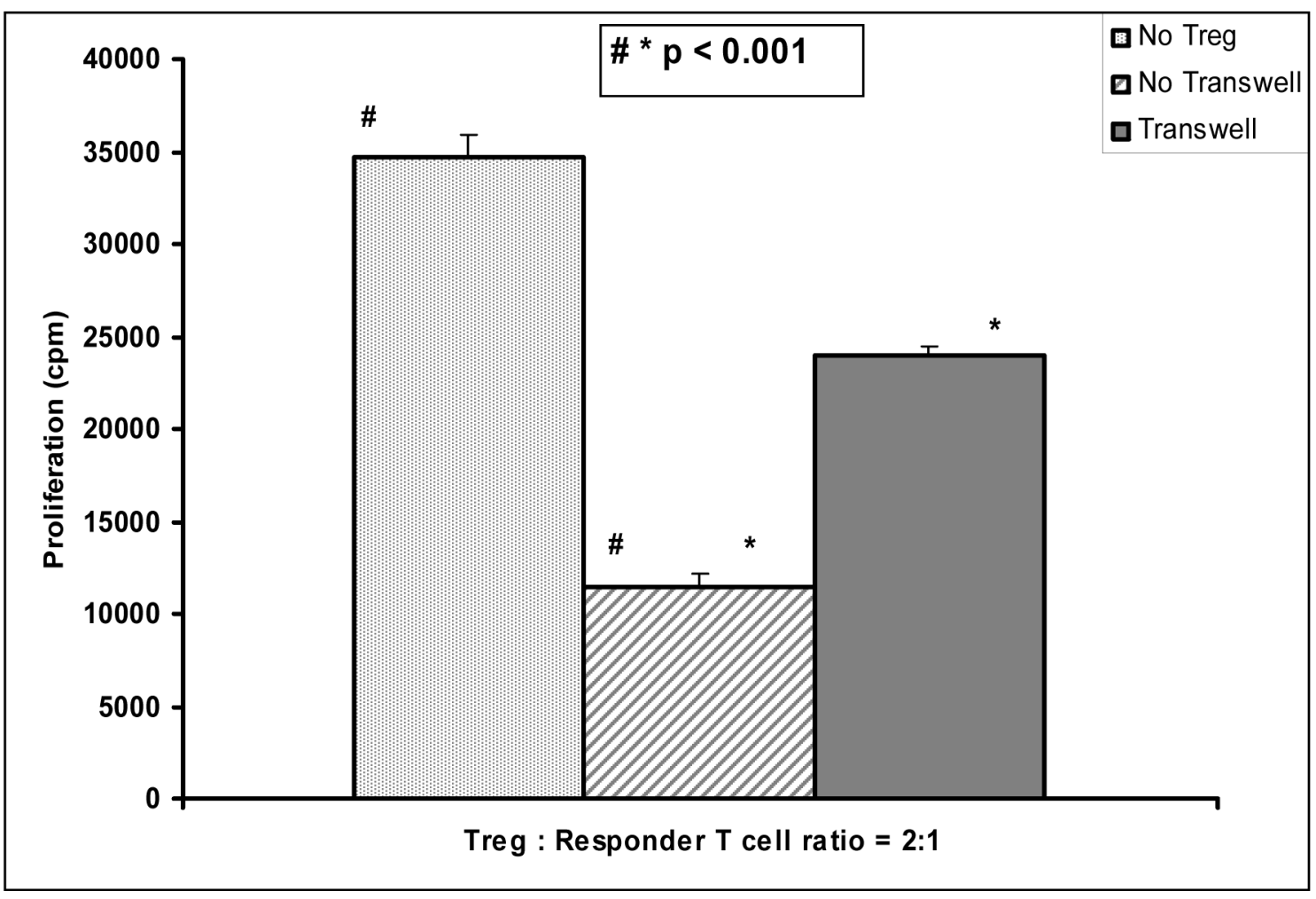

Figure 3. $\mathrm{CD5}^{-1-} \mathrm{T}_{\text {reg }}$ cells require cell-cell contact with the responder $\mathrm{T}$ cells

$5 \times 10^{5} \mathrm{CD}^{+} \mathrm{CD} 25^{-}$responder T cells from C57BL/6 wild type spleen and lymph node cells were incubated with equal number of APC and $10 \mu \mathrm{g} / \mathrm{ml}$ anti-CD3 in the presence of $10 \times$ $10^{5} \mathrm{CD}^{+} \mathrm{CD}^{+} 5^{+} \mathrm{T}_{\text {reg }}$ cells from $\mathrm{CD}^{-/-}$mice in a 24 -well plate. A Transwell ${ }^{\mathrm{R}}$ (pore size 0.4 $\mu \mathrm{m}$ ) insert was used to separate the $\mathrm{T}_{\text {reg }}$ cells from responder $\mathrm{T}$ cells wherever indicated. Mean proliferation $( \pm S E)$ response of triplicate cultures is plotted. The symbols $*$ and \# indicate that the differences between the groups with the same symbols are statistically significant with a $p<0.001$. 


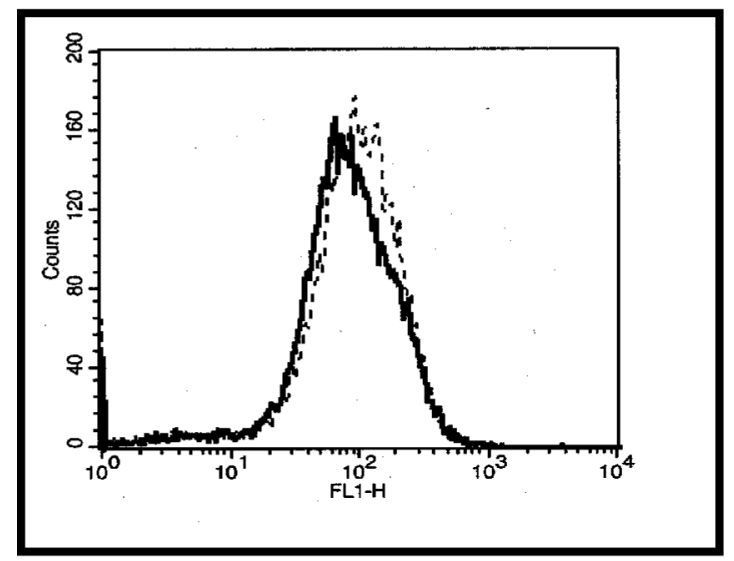

Resting state

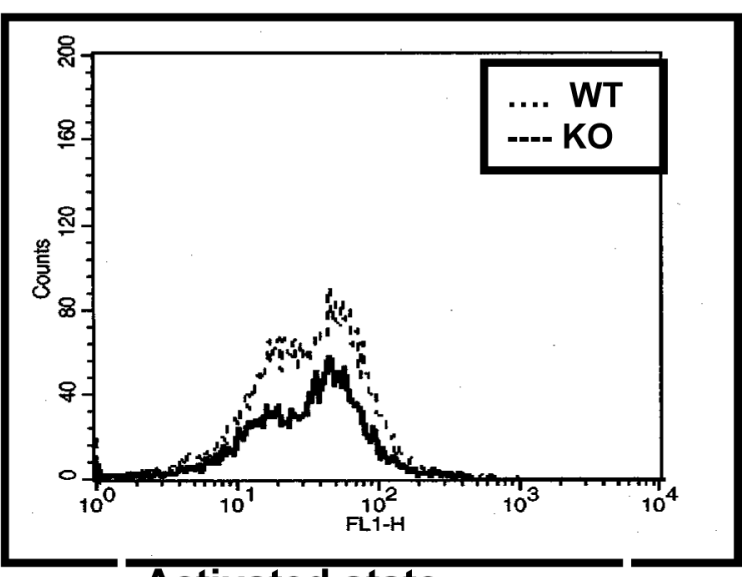

Activated state

Figure 4. $\mathrm{CD5}^{-/-}$and wild type $\mathrm{CD4}^{+} \mathrm{CD25}^{+} \mathrm{T}_{\text {reg }}$ cells express similar levels of GITR $5 \times 10^{4}$ sort purified $\mathrm{CD}^{+} \mathrm{CD} 25^{+} \mathrm{T}_{\text {reg }}$ cells (resting state) and $\mathrm{T}_{\text {reg }}$ cells treated with soluble anti-CD3 antibody $(6 \mu \mathrm{g} / \mathrm{ml})$ for 48 hours (activated state) from 3 month old C57BL/6 wild type or $\mathrm{CD}^{-/-}$mice were stained with supernatant from DTA-1 hybridoma and anti-rat Ig $\sim$ FITC secondary antibody. Flow cytometry analysis shows overlay of the staining from wild type (*-*) and $\mathrm{CD}^{-1-}$ mice (-). Results are representative of two independent analyses. 


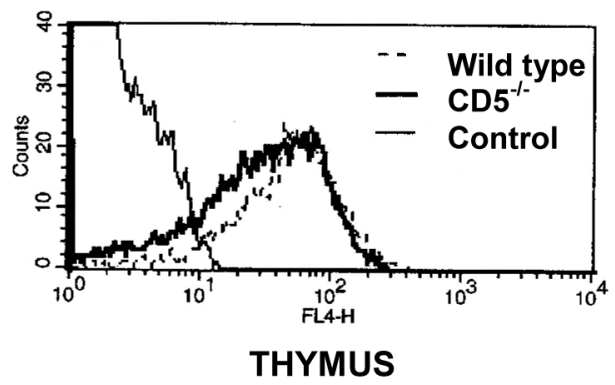

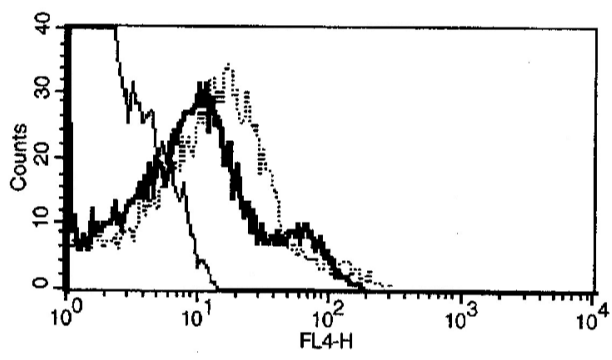

LYMPH NODE

Spleen

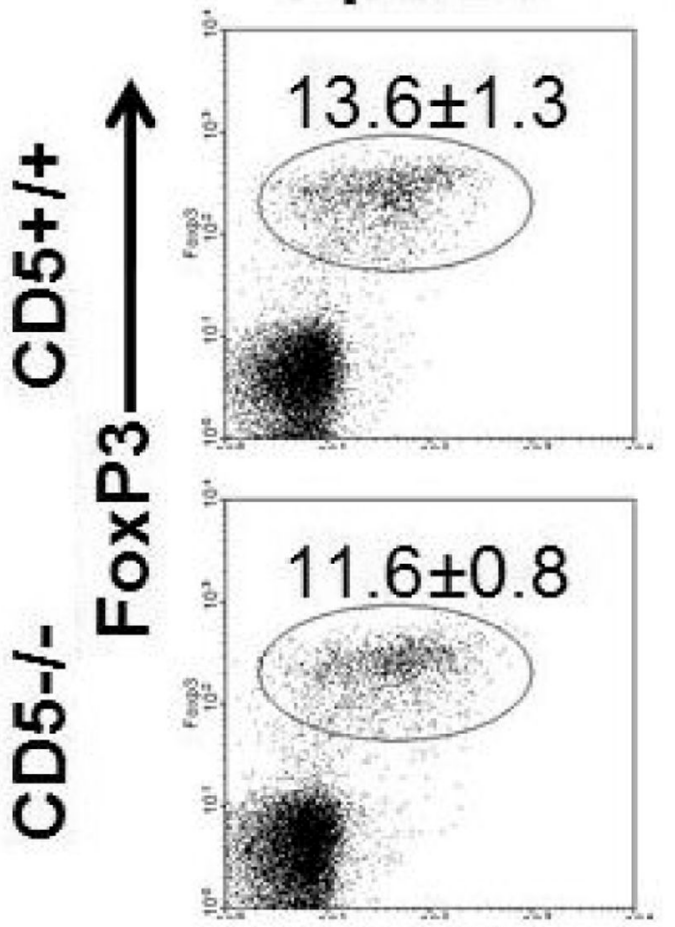

CD25



SPLEEN

Lymph Node
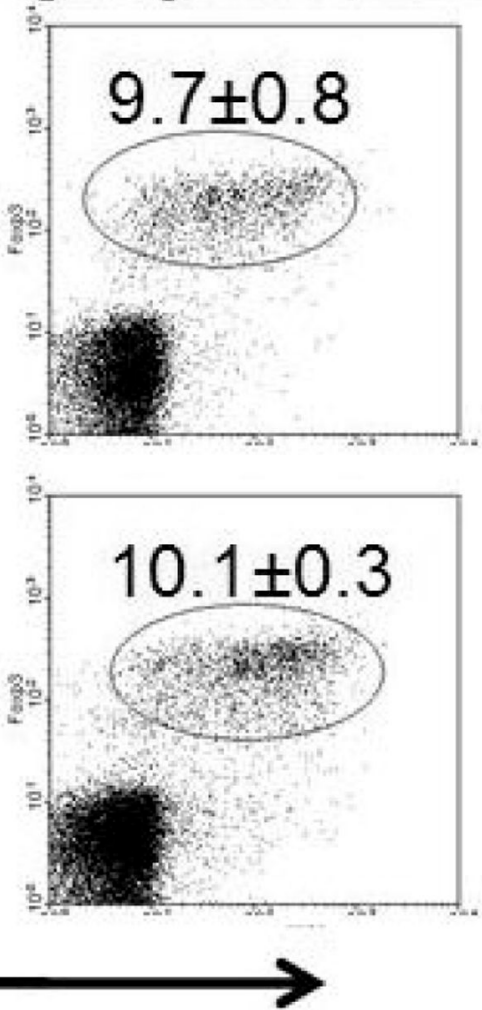

Figure 5. Intracellular Foxp3 levels in lymphoid organs of $\mathrm{CD5}^{-/-}$mice are similar to those in wild type strain 
(A) Thymocytes, lymph node cells and splenocytes from 3 month old C57BL/6 wild type and $\mathrm{CD}^{-1-}$ mice were stained for cell surface expression of CD4 and CD25. The cells were then permeabilized and stained for intracellular expression of Foxp3. Histograms are overlays of Foxp3 expression on gated $\mathrm{CD} 4{ }^{+} \mathrm{CD} 25^{+} \mathrm{T}_{\text {reg }}$ cells from the lymphoid organs or wild type

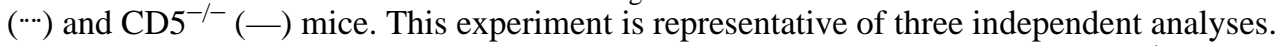
(B) Lymph node cells and splenocytes from 3-4 month old B6-Ly 5.1 mice $\left(\mathrm{CD}^{+/+}\right)$and age matched $\mathrm{CD}^{-1-}$ mice in B6-Ly 5.1 background $\left(\mathrm{CD}^{-1-}\right)$ were stained as above. Shown is a dot plot of CD25 and Foxp3 expression indicating the \% positive cells \pm SE from three mice in each group. 


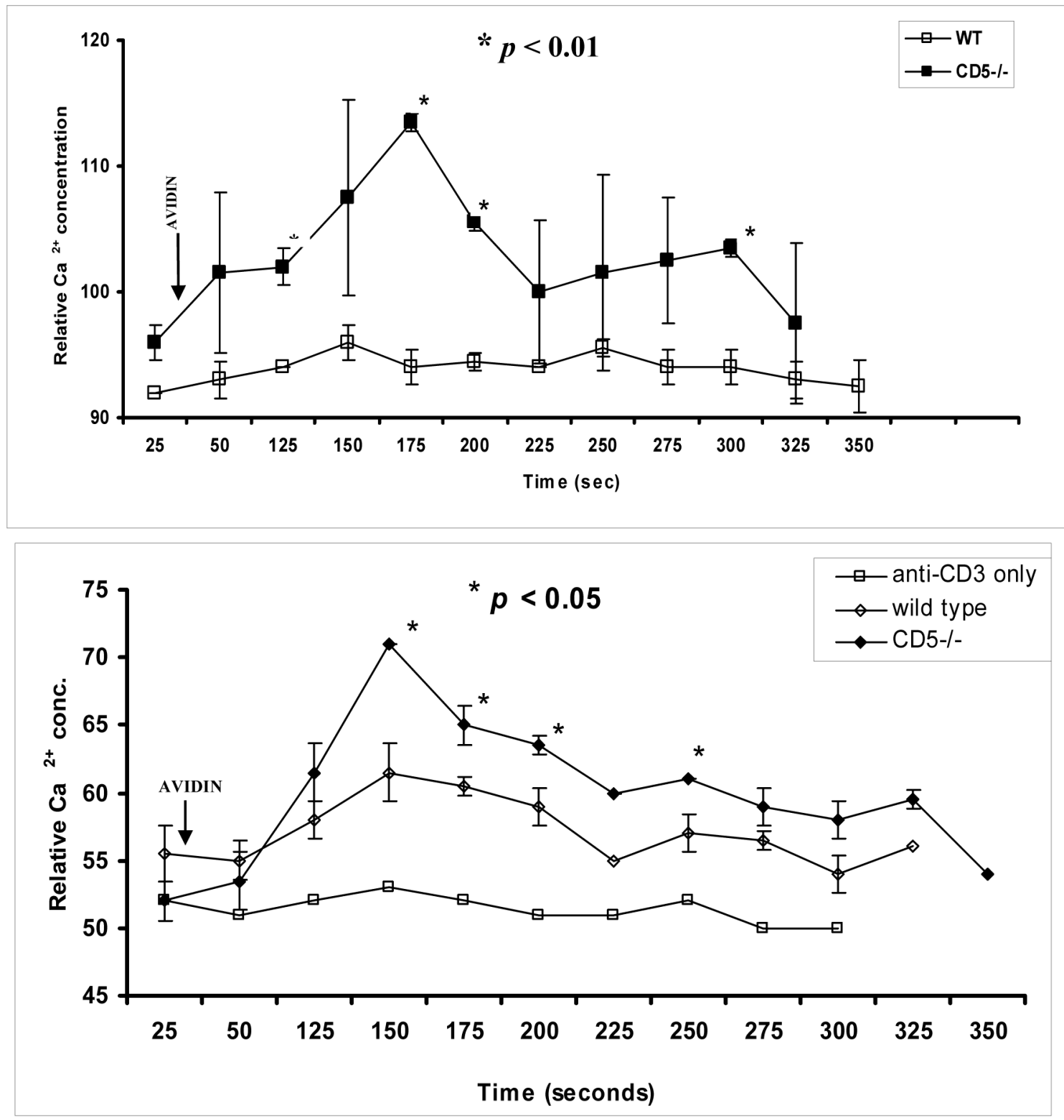

Figure 6. $\mathrm{CD4}^{+} \mathrm{CD25}^{+} \mathrm{T}_{\text {reg }}$ cells from $\mathrm{CD5}^{-/-}$thymocytes elicit a better $\mathrm{Ca}^{2+}$ flux in response to CD3 stimulation than $T_{\text {reg }}$ cells from wild type thymocytes

(A) Thymocytes from either 5 month old wild type (C57BL/6) or $\mathrm{CD}^{-/-}$mice were loaded with Indo-1, stained with $\alpha-\mathrm{CD} 8 \sim \mathrm{PE}$ and $\alpha-\mathrm{CD} 25 \sim \mathrm{FITC}$ and treated with $5 \mu \mathrm{g} / \mathrm{ml}$ biotinylated anti-CD3 as described in Methods. Cells were stimulated with $20 \mu \mathrm{g} / \mathrm{ml}$ avidin at the time indicated by the arrow. The panel shows changes in the ratio of Indo- 1 mean fluorescence intensity that are indicative of relative $\mathrm{Ca}^{2+}$ concentration in the $\mathrm{CD}^{+}{ }^{+} \mathrm{CD} 25^{+}$(gated as $\mathrm{CD}^{-} \mathrm{CD}^{-} 5^{+}$cells $) \mathrm{T}_{\text {reg }}$ cells. Results represent mean $( \pm \mathrm{SE})$ of triplicate determinations and plotted as a function of time (seconds). Graph is representative of two independent experiments. * indicates $p<0.05$ when comparing the responses of wild type and CD5 knockout cells.

(B) Thymocytes from 5-6 month old wild type or $\mathrm{CD}^{-1-}$ mice were loaded with Indo-1 and stained with fluorochrome conjugated antibodies as in (A) and treated with biotinylated antiCD3 $(1 \mu \mathrm{g} / \mathrm{ml})$ alone $(\square)$ or along with biotinylated anti-CD4 $(2 \mu \mathrm{g} / \mathrm{ml})$ and anti-CD28 $(2 \mu \mathrm{g} /$ $\mathrm{ml})$ antibodies. Cells were then stimulated with avidin $(20 \mu \mathrm{g} / \mathrm{ml})$ after obtaining a $30 \mathrm{~s}$ baseline 
$\mathrm{Ca}^{2+}$ concentration. The change in the ratio of Indo-1 MFI in the $\mathrm{T}_{\text {reg }}$ cells is plotted as a function of time (seconds). Results represent mean \pm SE of triplicate determinations. * indicates difference between the responses of wild type and CD5 deficient mice is statistically significant at $p<0.05$. Results are representative of three separate experiments. 


\section{Colon Tissue mRNA}

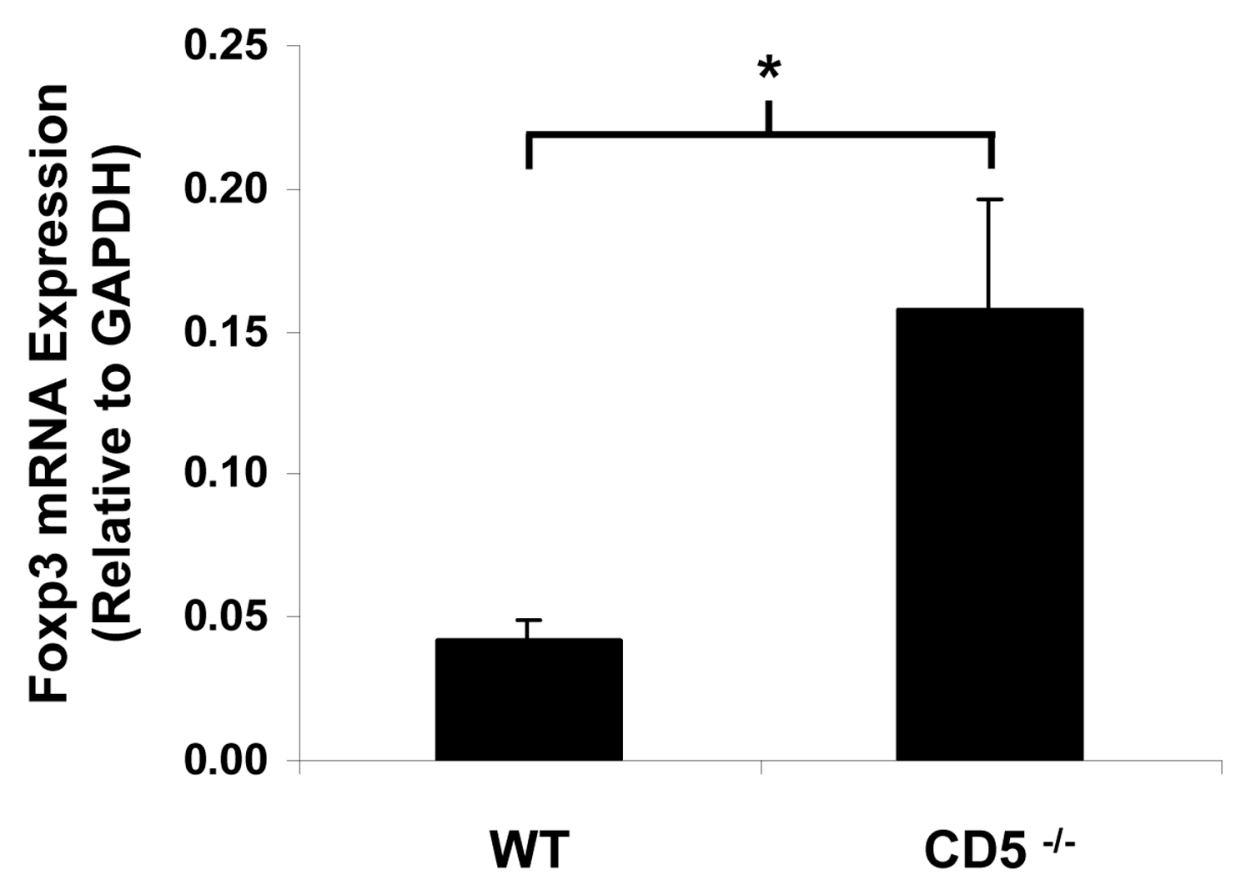

Figure 7. Cells from the colon of $\mathrm{CD5}^{-/-}$mice express higher Foxp3 mRNA than cells from the colon of WT mice

Colons from $\mathrm{CD}^{-1-}$ or C57BL/6 (WT) mice were homogenized for mRNA extraction. The mRNA was used for reverse transcription PCR for GAPDH and Foxp3 amplification, which was subsequently quantified by band density analysis. Data are presented as Foxp3 amplicon band density relative to GAPDH $\pm \mathrm{S}$.E. Data are representative of 3 separate studies. ${ }^{*}=p<$ 0.05 compared to Foxp3 expression from WT colons. 
A

4 -WT $0 \%$ DSS

$\square$ WT $3 \%$ DSS

$\square \mathrm{CD} 5-/-\quad 0 \% \mathrm{DSS}$

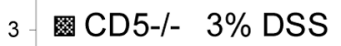

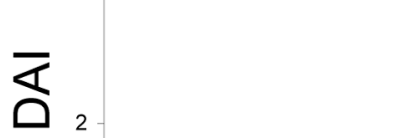

B

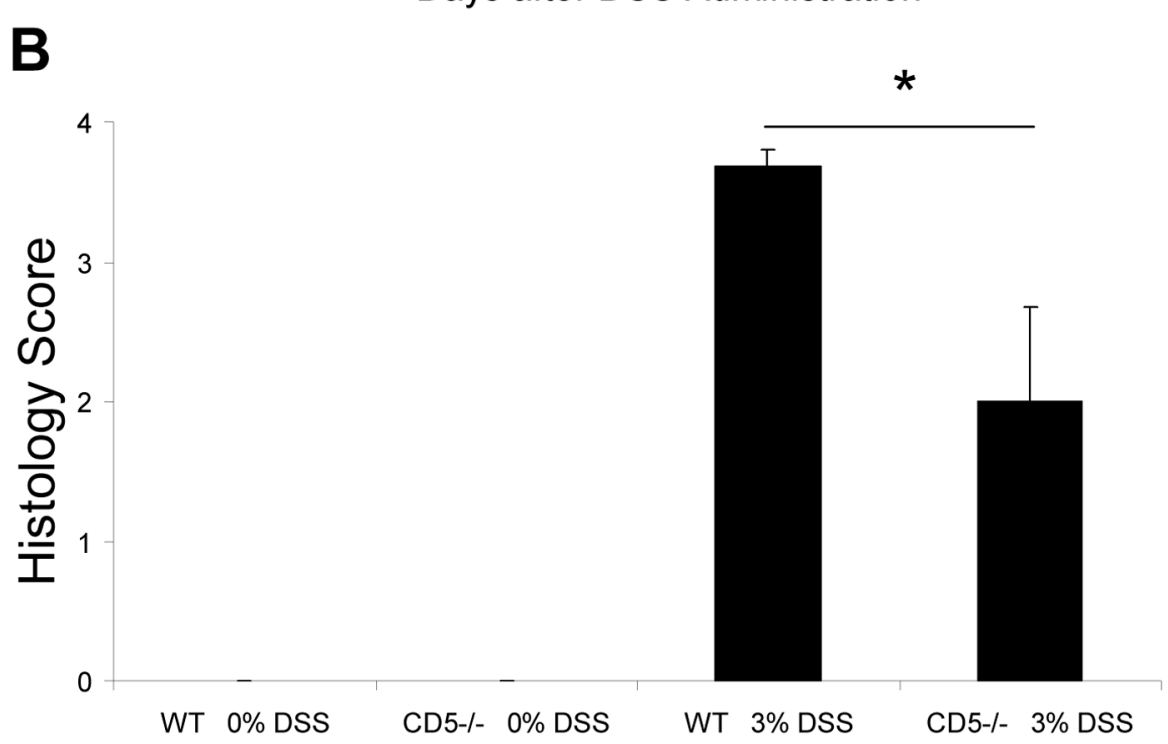

Days after DSS Administration 
B6

0\% DSS

\section{$3 \%$ DSS}
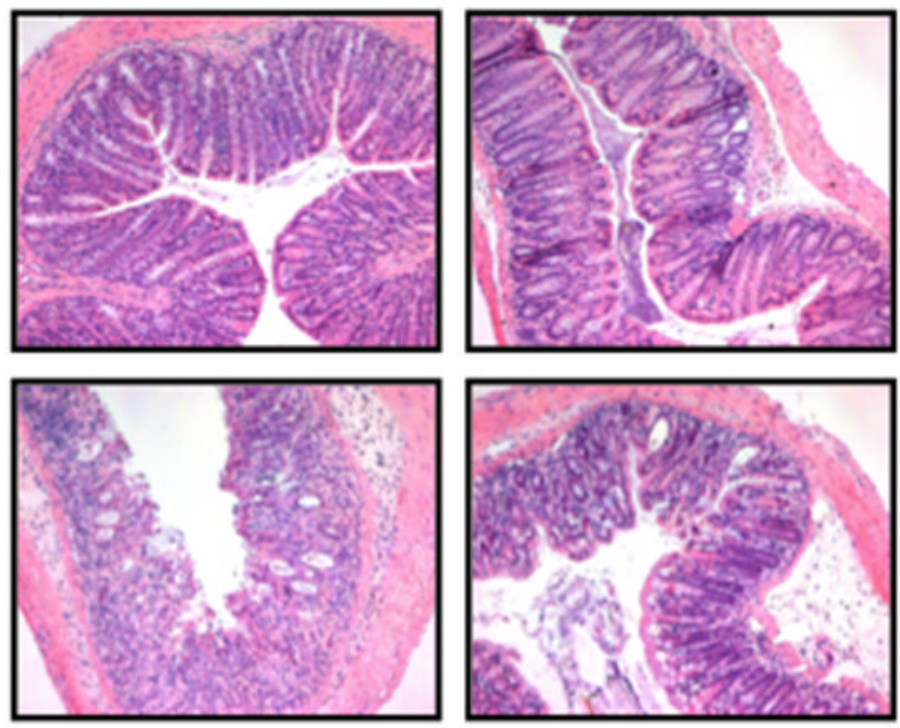

CD5-



Figure 8. DSS-induced colitis is less severe in $\mathrm{CD5}^{-/-}$mice compared to WT mice (A) Groups of 4 mice were administered 3\% DSS in drinking water or allowed normal drinking water for 7 days. The Disease Activity Index (DAI), based on weight loss, stool consistency, and rectal bleeding, was determined for each mouse. This experiment was repeated two additional times with similar results. Data are presented as mean DAI \pm S.E. $*=p<0.05$ compared to DSS treatment alone. Groups: $\square$-WT (0\% DSS); $\square$-WT (3\% DSS); $\square-$ CD5 $^{-/-}$ (0\% DSS); - $\mathrm{CD}^{-1-}$ (3\% DSS).

$(\mathbf{B}, \mathbf{C})$ After sacrifice on day 7, colons were removed and tissue sections were prepared for histology by $\mathrm{H} \& \mathrm{E}$ staining. Histology sections were scored for disease activity \pm S.E. Data are representative of 3 separate studies. $*=p<0.05$ compared to DSS treatment alone. 
Table I

Expression of cell surface GITR on $\mathrm{T}_{\text {reg }}$ cells from wild type and $\mathrm{CD}^{-1-}$ mice

\begin{tabular}{l|c|c|} 
Cell type & $\%$ GITR $^{+}$Resting cells & $\%$ GITR $^{+}$activated cells \\
\hline
\end{tabular}

\begin{tabular}{l|c|c} 
WT responder cells & $1 \pm 0$ & $35 \pm 16$ \\
\hline
\end{tabular}



\begin{tabular}{c|c|c}
$\mathrm{CD}^{-1-}$ responder cells & $1 \pm 0$ & $30 \pm 20$ \\
\hline
\end{tabular}

\begin{tabular}{c|c|c}
$\mathrm{CD} 5^{-1-} \mathrm{T}_{\text {reg }}$ cells & $1 \pm \pm 6$ & $44 \pm 7$ \\
\hline
\end{tabular}

$5 \times 10^{4} \mathrm{CD}^{+} \mathrm{CD} 25^{+} \mathrm{T}_{\mathrm{reg}}$ cells and $\mathrm{CD} 4^{+} \mathrm{CD} 25^{-}$responder $\mathrm{T}$ cells from wild type $\mathrm{C} 57 \mathrm{BL} / 6$ and $\mathrm{CD} 5^{-/-}$mice were purified by cell sorting. They were rested or activated with anti-CD3 for $48 \mathrm{~h}$ before staining with anti-DTA- 1 antibody as described in Methods. Mean \pm SE of $\%$ GITR positive cells from three independent experiments is shown. Each experiment involved $3-5$ mice for isolation of $\mathrm{T}_{\text {reg }}$ cells. The differences between wild type and CD5 null mice are not statistically significant $(p>0.05)$ for both responder cells and $\mathrm{T}_{\text {reg cells. }}$ 


\section{Table II}

Intracellular Foxp3 expression by flow cytometry.

\begin{tabular}{|c|c|c|c|c|}
\hline & \multicolumn{2}{|c|}{ wild type } & \multicolumn{2}{|c|}{$\mathrm{CD5}^{-1-}$} \\
\hline & \% Foxp3 +ve Responder cells & $\%$ Foxp3 +ve $\mathrm{T}_{\text {reg }}$ cells & \% Foxp3 +ve Responder cells & $\%$ Foxp3 +ve $T_{\text {reg }}$ cells \\
\hline Spleen & $2 \pm 1$ & $26 \pm 20$ & $2 \pm 1$ & $26 \pm 0$ \\
\hline Thymus & $4 \pm 4$ & $16 \pm 11$ & $6 \pm 6$ & $23 \pm 11$ \\
\hline
\end{tabular}

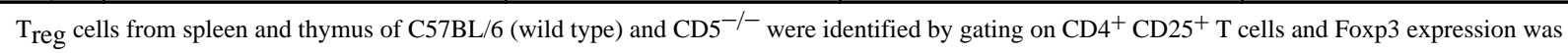
determined by intracellular staining as described in the Methods. Results from two independent analyses are represented as mean \pm SD of $\% \mathrm{CD}^{+}$ $\mathrm{CD} 25^{+} \mathrm{T}_{\text {reg }}$ cells staining positive for Foxp3. The differences between wild type and CD5 null mice are not statistically significant ( $\left.\mathrm{p}>0.05\right)$ for both responder cells and $\mathrm{T}_{\text {reg }}$ cells. 
Table III

Intracellular Foxp3 expression in mesenteric lymph nodes.

\begin{tabular}{|l|l|c|c|c|}
\hline & \multicolumn{2}{|c|}{ wild type } & \multicolumn{2}{c|}{ CD5 $^{-1-}$} \\
\cline { 2 - 5 } & \% CD4 $^{+} \mathbf{F o x p 3}^{+}$ & MFI & \% CD4 $^{+} \mathbf{F o x p 3}^{+}$ & MFI \\
\hline Spleen & $25.5 \pm 1.4$ & $384 \pm 44$ & $25.8 \pm 1.1$ & $400 \pm 47$ \\
\hline Mesenteric LN & $19.25 \pm 0.8$ & $345 \pm 25$ & $15.8 \pm 0.6$ & $322 \pm 28$ \\
\hline
\end{tabular}

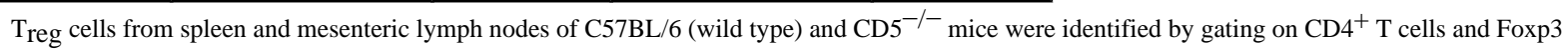
expression was determined by intracellular staining as described in the Methods. Results from 4 mice per group are represented as mean \pm SE of $\%$

$\mathrm{CD} 4{ }^{+} \mathrm{T}$ cells staining positive for Foxp3 and mean fluorescence intensity (MFI). The differences between wild type and CD5 null mice are not statistically significant ( $p>0.05$ ) for both responder cells and $\mathrm{T}_{\text {reg }}$ cells. 